\title{
Risk-Based Capital and Firm Risk Taking in Property-Liability Insurance
}

\author{
Jiang Cheng ${ }^{\mathrm{a}}$ and Mary A. Weiss ${ }^{\mathrm{b}}$

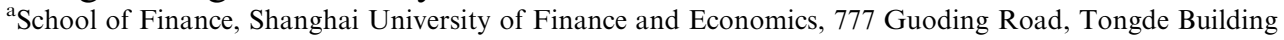 \\ 317, Shanghai 200433, China. \\ E-mail: cheng.jiang@mail.shufe.edu.cn \\ ${ }^{\mathrm{b}}$ Risk, Insurance \& Healthcare Management Department, Fox School of Business, 1801 Liacouras Walk 6th \\ Floor (006-07), Temple University, Philadelphia, PA 19122, U.S.A.
}

This research investigates the relationship between capital and risk in property-liability insurers from 1993 to 2007. Three-stage least squares estimation is used to investigate the relationship between capital and two types of risk: underwriting and asset risk. Overall the results suggest that risk and capital are positively related, so that capital increases are associated with increases in investment and underwriting risk. This positive relationship was not consistently significant in 1993, prior to the implementation of risk-based capital (RBC) requirements. Both under-capitalised insurers and marginally adequately capitalised insurers adjusted their capital and risk towards firm targets at a higher speed than wellcapitalised insurers in the post-RBC period. But underwriting and asset risk also increased for less well-capitalised insurers.

The Geneva Papers (2013) 38, 274-307. doi:10.1057/gpp.2013.2

Keywords: risk-based capital; regulatory effect; capital; risk

Article submitted 6 January 2012; accepted 14 January 2013; published online April 2013

\section{Introduction}

Maintaining insurer solvency has always been a focal point of insurance regulation. U.S. regulators use various methods to promote insurers' financial strength and protect policyholders from losses due to insolvency. One important tool is embodied in the riskbased capital (RBC) requirements that went into effect in the U.S. property-liability insurance industry in 1994. An important feature of the RBC system is that it mandates intervention by the regulator when risk-based capital levels are deemed deficient. The degree of intervention varies with the degree of deficiency, and ranges from regulatory approval of an insurer action plan to correct the deficiency to mandatory takeover of the insurer. Because it contains mandatory requirements, the RBC system is at least partly designed to eliminate regulatory forebearance in the industry.

The research by Cummins and $\mathrm{Nini}^{1}$ suggests that the imposition of RBC requirements may have been partly responsible for increased capital levels in the propertyliability insurance industry in the 1990s, enhancing solvency. But considerable research

\footnotetext{
${ }^{1}$ Cummins and Nini (2002).
} 
criticises the RBC system. For example, Cummins et al. ${ }^{2}$ hypothesise that imperfections in the existing RBC system will likely distort insurer's behaviour in undesirable and unintended ways so as to avoid being incorrectly identified as needing regulatory attention. ${ }^{3}$ Another possibility is that insurers (especially weak insurers) will exploit anomalies in the RBC formula so as to make their financial position appear to be more favourable than it really is.

To understand the role of $\mathrm{RBC}$ requirements on insurer behaviour, the relationship between insurer capital and risk must be examined. The most reasonable relationship to posit between capital and risk is that they are positively related, and this is the result found by Cummins and Sommer ${ }^{4}$ using a sample period of 1979-1990. Accordingly, we posit that insurers will increase their risk simultaneously while raising capital to meet the RBC requirement. Further, we expect that RBC requirements should have had minimal impact on capital or risk of insurers if most insurers were already more than adequately capitalised (i.e. had capital in excess of RBC requirements). For marginally capitalised insurers, where RBC requirements were binding or nearly binding, the imposition of RBC requirements should have resulted in an improvement in the solvency position. That is, the latter insurers would have had a stronger incentive to adjust risk and capital to meet the RBC capital requirements.

In spite of these possibilities associated with the relationship between capital and risk and the role of $\mathrm{RBC}$ in practice, little research is aimed at addressing the relationship between capital and risk both before and after RBC requirements. ${ }^{5}$ The purpose of this study is to determine the relationship between insurers' capital and risk from 1994 to 2007 (after RBC was adopted). To provide at least some idea of whether the relationship between risk and capital changed after the imposition of RBC requirements in 1994, the period 1993 is examined as well. ${ }^{6}$ Further, this research estimates the relationship between risk and capital for marginally adequately capitalised insurers and under-capitalised insurers. ${ }^{7}$

The sample of insurers studied consists of pooled, cross-sectional U.S. propertyliability insurers included in the NAIC's database for the period 1992-2007. Thus this research also updates the analysis of Cummins and Sommer. ${ }^{4}$ Following a long line of

\footnotetext{
${ }^{2}$ Cummins, Harrington and Niehaus (1994).

${ }^{3}$ Most studies of RBC have focused on the effectiveness of RBC requirements in predicting propertyliability insurer insolvencies. Research suggests that RBC results are not good predictors of insolvency (e.g. Cummins et al., 1995, 1999). Cheng and Weiss (2012a) find that the accuracy of the RBC ratio in predicting insolvencies is inconsistent over time.

${ }^{4}$ Cummins and Sommer (1996).

${ }^{5}$ Petroni and Shackelford (1996) study changes in stock life insurer's investment portfolios occurring after implementation of RBC to determine if $\mathrm{RBC}$ had an effect. The research concludes that there was little change in stock life insurers' investment portfolios during their sample period (1989-1993), suggesting that perhaps insurers may have chosen a mechanism to manage RBC reported results other than investment restructuring. Shim (2010) addresses the impact of capital-based regulation on portfolio risk and capital determination in property-liability insurance. However, he does not explicitly study how $\mathrm{RBC}$ requirements might have affected the capital and risk relationship between the pre- and post-RBC regimes.

${ }^{6}$ It would be desirable to perform our analysis on more years preceding the implementation of RBC requirements; however, these data are unavailable.

${ }^{7}$ Under- and marginally adequate capitalisation is determined relative to thresholds in the RBC system.
} 
literature, the model used allows for capital and risk positions to be determined simultaneously, so that three-stage least squares (3SLS) estimation is used to estimate the capital and risk equations. ${ }^{8}$ The 3 SLS model incorporates the possibility that insurers may be unable to adjust to their target risk or capital levels over the course of a year. That is, the capital and risk equations estimated allow for partial adjustment of capital and risk. The capital measures rely on surplus, while measures of insurer risk are based on asset and underwriting risk.

To measure the effect of $\mathrm{RBC}$ implementation on under- and marginally adequately capitalised insurers, indicator variables that reflect relative capitalisation of insurers (using the RBC system) are included in the models. In addition, variables are added that provide evidence of whether under- or marginally adequately capitalised insurers adjusted to their desirable target capital and risk ratios more quickly than adequately capitalised insurers. And the inclusion of these variables represents an innovation from Cummins and Sommer and Shim. ${ }^{8}$ The results with respect to these variables can be interpreted as the effect of relative undercapitalisation on the capital and risk relationship for these insurers; in addition, these variables provide insight into the impact of regulatory pressure on these insurers after implementation.

By way of preview, the results overall suggest that risk and capital are positively related, so that capital increases are associated with increases in asset and underwriting risk. This positive relationship was not consistently significant in 1993, however, prior to the implementation of RBC requirements. Over the sample period 1994-2007, asset and underwriting risk increased for under-capitalised insurers. Finally, both under- and marginally adequately capitalised insurers adjusted their capital and risk towards firm targets at a higher speed than wellcapitalised insurers in the post-RBC period.

This research is important because the RBC system is currently under review by the NAIC. In addition, the default calculation of capital requirements under Solvency II relies, at least in part, on risk-based charges. Therefore, it is desirable to understand how insurers respond to capital requirements such as those imposed by RBC. Of particular interest is whether RBC requirements in general are likely to lead to better capitalisation in the insurance industry. This research suggests that, to the extent that $\mathrm{RBC}$ requirements increased capitalisation in the insurance industry, an offsetting increase in risk occurred. The most important concern for regulators perhaps is the evidence that under-capitalised insurers increased asset and underwriting risk in the post-RBC period.

The remainder of this research is organised as follows. In the next section, the RBC requirements for insurers are briefly described. Following this, the hypotheses are presented. The next sections focus on the methodology and the data description. The results are contained in the subsequent section, and the last section concludes.

\footnotetext{
${ }^{8}$ Shrieves and Dahl (1992); Cummins and Sommer (1996); Jacques and Nigro (1997); Aggarwal and Jacques (2001) and Shim (2010), among others.
} 
Table 1 "Risk" categories based on the NAIC RBC ratios (TAC/ACL RBC)

\begin{tabular}{|c|c|c|c|}
\hline $\begin{array}{l}\text { NAIC insurer } \\
\text { "risk" category }\end{array}$ & $R B C$ ratio & $\begin{array}{l}\text { NAIC regulatory } \\
\text { action level }\end{array}$ & $\begin{array}{l}\text { Classifications } \\
\text { in this study }\end{array}$ \\
\hline $\mathrm{C} 1$ & $\mathrm{RBC}$ ratio $\geqslant 2$ & No action need & N/A \\
\hline $\mathrm{C} 2$ & $1.5<=\mathrm{RBC}$ ratio $<2$ & Company action level & $\begin{array}{l}\text { Moderately financially distressed/ } \\
\text { Under-capitalised insurers }\end{array}$ \\
\hline $\mathrm{C} 3$ & $1<=\mathrm{RBC}$ ratio $<1.5$ & Regulatory action level & $\begin{array}{l}\text { Moderately financially distressed/ } \\
\text { Under-capitalised insurers }\end{array}$ \\
\hline $\mathrm{C} 4$ & $0.7<=\mathrm{RBC}$ ratio $<1$ & Authorised control level & $\begin{array}{l}\text { Moderately financially distressed/ } \\
\text { Under-capitalised insurers }\end{array}$ \\
\hline $\mathrm{C} 5$ & $\mathrm{RBC}$ ratio $<0.7$ & Mandatory control level & $\begin{array}{l}\text { Highly financially distressed } \\
\text { insurers/Under capitalized insurers }\end{array}$ \\
\hline
\end{tabular}

Note: TAC is the Total Adjusted Capital, and ACL RBC is the Authorised Control Level RBC.

\section{The RBC system}

Capital adequacy is assessed with the $\mathrm{RBC}$ ratio, defined as the ratio of total adjusted capital (TAC) to RBC. TAC is composed primarily of the surplus (or equity) of an insurer. RBC itself is determined from a formula that attaches weights (or factors) to detailed, risk-related items in the insurer's financial statements. The risks encompassed by $\mathrm{RBC}$ requirements are primarily underwriting and asset risk ${ }^{9}$; these risks account for 87 per cent of total RBC. ${ }^{10}$

Based on their $\mathrm{RBC}$ ratios, insurers are classified into one of five ranked categories depending on the degree of any capital deficiency. The RBC categories (and required regulatory/insurer action) are $\mathrm{C} 1$ (no action needed), $\mathrm{C} 2$ (insurer required to file a plan with the insurance commissioner detailing its financial condition and how it proposes to correct deficiency), C3 (regulator examines the insurer and institutes corrective action if necessary), C4 (regulator has legal grounds to rehabilitate the company) and C5 (regulator required to seize the insurer). ${ }^{11}$ Table 1 specifies the thresholds corresponding to each of these categories. For example, insurers with an $\mathrm{RBC}$ ratio greater than or equal to 2 are associated with no regulatory action.

Several features of the RBC requirements are noteworthy for purposes of this study. The lack of granularity in the risk loadings for invested assets has been criticised. For example, there is no variation in the RBC factors for assets with different durations, and no distinction is made in risk factors for assets rated from AAA to A-, although clearly there is a difference in risk. Also, charges do not differ for different types of bonds (e.g. RMBS, CMBS, etc.) Most likely the reason that at least some of these

\footnotetext{
${ }^{9}$ More specifically, six main types of risk are analysed in the RBC system: off-balance sheet risks, investments in insurance company affiliates, investment in bonds, investment in stocks, credit risk and pricing risk. Pricing risk is estimated via underwriting loss and expense reserves and net premiums written by line.

${ }^{10}$ Cummins and Sommer (1996, p. 1081).

${ }^{11}$ Cummins et al. (1995).
} 
Table 2 Insurer RBC risk classification

\begin{tabular}{llrlllll}
\hline Year & $C 11$ & $C 12$ & $C 2$ & $C 3$ & $C 4$ & $C 5$ & Total for year \\
\hline 1993 & 1,688 & 111 & 42 & 16 & 9 & 21 & 1,887 \\
1994 & 1,613 & 90 & 15 & 10 & 3 & 18 & 1,749 \\
1995 & 1,795 & 108 & 29 & 11 & 6 & 12 & 1,961 \\
1996 & 1,783 & 145 & 28 & 14 & 4 & 16 & 1,990 \\
1997 & 1,788 & 122 & 26 & 10 & 2 & 14 & 1,962 \\
1998 & 1,798 & 100 & 21 & 11 & 3 & 13 & 1,946 \\
1999 & 1,724 & 114 & 19 & 12 & 5 & 11 & 1,885 \\
2000 & 1,666 & 135 & 27 & 15 & 3 & 12 & 1,867 \\
2001 & 1,656 & 153 & 18 & 17 & 6 & 17 & 1,860 \\
2002 & 1,619 & 168 & 32 & 20 & 4 & 17 & 1,868 \\
2003 & 1,667 & 138 & 23 & 9 & 8 & 23 & 1,875 \\
2004 & 1,678 & 127 & 22 & 21 & 7 & 20 & 1,915 \\
2005 & 1,740 & 116 & 21 & 14 & 3 & 21 & 1,950 \\
2006 & 1,808 & 87 & 21 & 11 & 4 & 19 & 1,985 \\
2007 & 1,839 & 88 & 21 & 12 & 7 & & 28,558 \\
\hline
\end{tabular}

Note: This table presents the annual sample count in each category based on the NAIC RBC ratio. C11 is the category of well-capitalised insurers with $\mathrm{RBC}$ ratio $>=3 . \mathrm{C} 12$ is the category of marginally adequately capitalised insurers with $2 \leqslant \mathrm{RBC}$ ratio $<3$. C2 is the category of under-capitalised insurers with $1.5 \leqslant \mathrm{RBC}$ ratio $<2$. $\mathrm{C} 3$ is the category of under-capitalised insurers with $1 \leqslant \mathrm{RBC}$ ratio $<1.5$. $\mathrm{C} 4$ is the category of under-capitalised insurers with $0.7 \leqslant \mathrm{RBC}$ ratio $<1$. C5 is the category of highly financially distressed insurers with $\mathrm{RBC}$ ratio $<0.7$.

distinctions are not made in the $\mathrm{RBC}$ formula is that these issues were not as important when RBC was formulated as they are today. ${ }^{12}$ Unfortunately, there is no way to determine the extent to which, if at all, these criticisms affect the ability of RBC to distinguish effectively between insurers of varying risk. Table 2 contains a breakdown of the $\mathrm{RBC}$ ratio by category over time.

\section{Hypotheses development}

Several reasons exist to suggest that insurer capital and risk are positively related. ${ }^{13}$ If insurers are concerned with bankruptcy costs, then increases in risk would lead to higher capital and a positive relationship between risk and capital. Further, consumer awareness of insolvency will also incentivise insurers to raise capital when increasing firm risk taking. Finally, agency theory suggests that agency costs also lead to a positive relationship between risk and capital if managers, because of their substantial human

\footnotetext{
${ }^{12}$ Finally, RBC may be subject to some manipulation as it relies on insurers' estimates of losses incurred for each year and reserves. Prior research has found evidence that insurers do manipulate reserves, at least in the short term. See, for example, Weiss (1985).

${ }^{13}$ Shrieves and Dahl (1992); Cummins and Sommer (1996).
} 
investment in the insurer, offset increases in insurer risk by holding higher capital amounts. ${ }^{14}$ This is consistent with the finite risk hypothesis. ${ }^{15}$ Thus, Hypothesis 1 states:

Hypothesis 1: Insurers' risk and capital are positively related to each other.

The relationship between capital and risk and the effect of RBC should differ for financially distressed insurers compared with (more than) adequately capitalised insurers. For example, the positive relationship between risk and capital might be weakened, or might even be negative, for insurers close to financial distress. Moral hazard is posited to exist in the insurance industry because of guaranty funds. More specifically, insurers are not charged a risk-based default premium to cover costs in the event of their insolvency. Instead when an insurer becomes insolvent, solvent insurers are assessed a flat rate to cover insolvency costs. Thus maximising shareholders' wealth for insurers close to financial distress could entail increasing risk relative to capital to take advantage of the moral hazard posed by the guaranty fund system. This is in line with the excess risk argument subject to the risk-subsidy hypothesis in the life insurance industry. ${ }^{16}$ Similar reasoning is used in the banking industry when discussing the deposit insurance subsidy. ${ }^{17}$

However, guaranty fund coverage is much less complete than deposit insurance in the U.S. banking industry. For example, some lines of insurance are excluded from coverage such as most lines of commercial insurance, and maximum guaranty fund payment limits exist where coverage does apply. Thus the excessive risk-taking incentive is weaker in property-liability insurance than in banking, and policyholders have an incentive to monitor insurers for excessive risk-taking. This would counteract the incentive to take on excessive risk at least to some extent.

A more likely scenario is that insurers with relatively low capital buffers have tried to build appropriate buffers by raising capital and/or lowering risk compared with well-capitalised insurers. The capital buffer theory argues that insurers' results are exposed to exogenous shocks related to developments in the overall economy or the property-liability insurance industry; hence, insurers wish to insulate their capital from such shocks with a buffer. ${ }^{18}$ In addition, reducing risk or raising capital for these insurers can serve as a signal that they are in regulatory compliance leading to a reduction in regulatory costs. ${ }^{19}$ Not only is the level of capital and risk affected by the degree of capitalisation but also the speed with which property-liability insurers

${ }^{14}$ It is theoretically possible that the relationship between capital and risk may be negative due to flaws in the RBC formula. Specifically, some factor loadings may result in overweighting of some types of risk and underweighting of other risks. In this case, insurers can rearrange their underwriting and asset portfolios to "seemingly" less risky types of assets or lines of business that have factor loadings that are too low (given actual risk). Then actual risk would have increased while capital requirements would have decreased, resulting in a negative relationship. This type of behaviour would most likely be used by insurers for whom the $\mathrm{RBC}$ requirements are binding or close to binding for regulatory or rating agency purposes.

${ }^{15}$ Cummins and Sommer (1996); Baranoff and Sager (2002, 2003).

${ }^{16}$ Baranoff et al. (2007).

${ }^{17}$ See, for example, Shrieves and Dahl (1992).

${ }^{18}$ Koziol and Lawrenz (2009); Jokipii and Milne (2011).

19 Jacques and Nigro (1997). 
respond to their target capital and risk. Specifically, these insurers should move more quickly towards their targets.

Insurers with $\mathrm{RBC}$ deficiencies should have had a stronger response to RBC requirements as these insurers likely experienced regulatory pressure to improve capital positions (or decrease risk) within a relatively shorter time frame. Similar to marginally adequately capitalised insurers, insurers with RBC deficiencies are expected to have responded more quickly towards their target capital and risk levels than adequately or marginally adequately capitalised insurers. Thus Hypotheses $2 \mathrm{a}$ and $2 \mathrm{~b}$ state:

Hypothesis 2a: Under- and marginally capitalised insurers adjusted capital and/or risk to become better capitalised and/or less risky after imposition of $\mathrm{RBC}$ requirements.

Hypothesis 2b: The speed of adjustment to target capital and/or risk levels is relatively higher for weaker insurers than for well-capitalised insurers.

Imposition of $\mathrm{RBC}$ requirements has changed the cost-return trade-off between risk and capital in the insurance industry. The trade-off theory suggests that the cost/ benefit of reducing the capital level is higher/lower due to potential regulatory intervention for under- and marginally capitalised insurers. ${ }^{20}$ In this case, one would expect that capital levels for insurers in different RBC categories responded differently prior to the time RBC became effective than afterwards. Hypothesis 3 states:

Hypothesis 3: The relationship between risk and capital for insurers in varying financial condition were different prior to the imposition of $\mathrm{RBC}$ requirements than afterwards.

\section{Methodology}

The hypotheses' discussion indicates that a simultaneous relationship between risk and capital exists such that capital depends on risk and vice versa. Further, the imposition of RBC standards should have had an impact on both capital and risk. In this section, the partial adjustment models used in the simultaneous equations are specified. Following this, the measures of capital and risk are discussed. Next the control variables used in the analysis are explained.

\footnotetext{
${ }^{20}$ The "target" capital structure of under- and marginally capitalised insurers is likely to be affected by the institution of the RBC requirements. We acknowledge that our model cannot directly measure the "target" levels of capital, underwriting and asset risk (nor has prior research focused on this issue). We focus on comparing the change in relationship between capital and risk in property-liability insurance associated with the institution of RBC in this study. We also acknowledge our methodology is not powerful enough to completely disentangle how RBC could impact insurers' risk-taking behaviour. We thank an anonymous referee for pointing this out (Shim, 2010; Cheng and Weiss, 2012b).
} 


\section{Model specification}

The models used in Cummins and Sommer and Shrieves and Dahl with the modification of Aggarwal and Jacques is used in this research. ${ }^{8}$ More specifically, relative capital is modelled in a single equation, and two equations are used to specify relative risk. Insurers' risk decisions are assumed to entail underwriting risk and asset risk. ${ }^{21}$ Underwriting risk reflects the amount and types of business that the insurer underwrites each year, while asset risk reflects the asset quality of the insurer's investments.

Insurers may not be able to adjust their capital and risk positions to the desired, or target, levels instantaneously. Instead, it may take time for a firm to reach its targets. In this case, the endogenous changes in capital and risk can be specified as a partial adjustment model:

$$
\begin{gathered}
\left(\operatorname{Cap}_{i t}-\operatorname{Cap}_{i, t-1}\right)=\delta\left(\operatorname{Cap}_{i t}^{*}-\operatorname{Cap}_{i, t-1}\right)+\varepsilon_{i t}, \\
\left(\text { UndRisk }_{i t}-\text { UndRisk }_{i, t-1}\right)=\lambda\left(\text { UndRisk }_{i t}^{*}-\text { UndRisk }_{i, t-1}\right)+\omega_{\text {it }}, \\
\left(\text { AssetRisk }_{i t}-\text { AssetRisk }_{i, t-1}\right)=\rho\left(\text { AssetRisk }_{i t}^{*}-\text { AssetRisk }_{i, t-1}\right)+v_{i t},
\end{gathered}
$$

where Cape it $_{i t}$ is target firm capital, and UndRisk* and AssetRisk* are target underwriting and asset risk, respectively. The factors $\delta, \lambda$ and $\rho$ are partial adjustment factors, usually assumed to vary from zero to one. $\varepsilon_{i t}, \omega_{i t}$ and $v_{i t}$ are random, exogenous shocks to capital (perhaps caused by fluctuations in the macroeconomic environment). The subscript $i$ refers to insurer $i$, and $t$ refers to time. Cap ${ }_{i t}^{*}$, UndRisk ${ }_{i t}^{*}$ and AssetRisk ${ }_{i t}^{*}$ are assumed to depend on exogenous, firm-specific factors. For example, Cap ${ }_{i t}^{*}$ is assumed to be determined by firm-specific variables $X_{i t-1}$ (i.e. $\mathrm{Cap}_{i t}^{*}=A X_{t-1}$, where $A$ is a parameter vector and $X_{t-1}$ is a vector of firm characteristics). UndRisk ${ }_{i t}^{*}$ and AssetRisk ${ }_{i t}^{*}$ are assumed to be determined in a similar fashion. Capital, underwriting risk and investment risk are all assumed to depend on each other.

Regulatory pressure is assumed to affect the insurer's capital and underwriting and asset risk positions. Therefore, two indicator variables denoting relative financial strength/capitalisation are added to the equation to determine if insurers' financial condition affects capital and risk. More specifically, the RBC categorisation of insurers in Table 1 is used to distinguish between well-capitalised insurers and less well-capitalised/financially distressed insurers in this study. Insurers in category $\mathrm{C} 1$ with an RBC ratio greater than three are considered well-capitalised. Insurers that are in category 1 but close to the lower threshold for category 1 should have an incentive to build up a buffer of capital (or reduce risk). Thus insurers with $(2 \leqslant \mathrm{RBC}<3)$ are considered marginally adequately capitalised and are designated by the indicator variable marginally adequately capitalised in the models above. It is assumed that insurers in categories $\mathrm{C} 2$ to $\mathrm{C} 4$ are under some regulatory pressure to increase capital,

${ }^{21}$ The RBC formula identifies additional risks. However, some of these risks are likely to be more sticky in nature than asset and underwriting risk (e.g. investment in affiliates) or reflect past underwriting or reinsurance decisions (e.g. reserves' accuracy and reinsurance ceded). 
reduce risk, or both to improve their $\mathrm{RBC}$ ratios. ${ }^{22}$ Therefore, these insurers are classified as under-capitalised/financially distressed in this study. ${ }^{23}$ These insurers are designated in the model by the indicator variable Undercapitalisation. ${ }^{24,} 25$

We include lagged values of these regressors for two reasons. The primary reason is that the decision about capital and risk in year $t$ would depend on the distance of the firm from its optimal values, firm's resources to make adjustments and the regulatory pressure to change. The last effect is captured by whether or not the firm is under- or marginally capitalised in year $t-1 .^{26}$ The second reason to use lagged values is to mitigate the concern that the under-capitalisation and marginally adequate capitalisation indicators may be endogenous. The under- and the marginally adequately capitalised indicator variable are also interacted with $\mathrm{Cap}_{i t-1}, \mathrm{UndRisk}_{i, t-1}$ and AssetRisk ${ }_{i, t-1}$ in the equations below.

Finally after adding $\mathrm{Cap}_{i, t-1}$, UndRisk ${ }_{i, t-1}$ and AssetRisk $_{i, t-1}$ to both sides of Eqs. (1)-(3), respectively, the following system of equations results ${ }^{27}$ :

$$
\begin{aligned}
\operatorname{Cap}_{i t}= & \alpha_{0}+\alpha_{1} \text { UndRisk }_{i t}+\alpha_{2} \text { AssetRisk }_{i t}+\delta_{1} \mathrm{AX}_{t-1} \\
& +\alpha_{3} \text { Marginally Adequate Capitalisation }_{i, t-1}+\alpha_{4} \text { Undercapitalisation }_{i, t-1} \\
& +\left(1-\delta_{1}\right) \mathrm{Cap}_{i, t-1}-\delta_{2} \text { Marginally Adequate Capitalisation }_{i, t-1} \mathrm{Cap}_{i, t-1} \\
& -\delta_{3} \text { Undercapitalisation }_{i, t-1} \mathrm{Cap}_{i, t-1}+\tau_{i t}
\end{aligned}
$$

$$
\begin{aligned}
\text { UndRisk }_{i t}= & \beta_{0}+\beta_{1} \text { Cap }_{i t}+\beta_{2} \text { AssetRisk }_{i t}+\lambda_{1} \mathrm{AX}_{t-1}+\beta_{3} \text { Marginally Adequate Capitalisation }_{i, t-1} \\
& +\beta_{4} \text { Undercapitalisation }_{i, t-1}+\left(1-\lambda_{1}\right) \text { UndRisk }_{i, t-1} \\
& -\lambda_{2} \text { Marginally Adequate Capitalisation }_{i, t-1} \text { UndRisk }_{i, t-1} \\
& -\lambda_{3} \text { Undercapitalisation }_{i, t-1} \text { UndRisk }_{i, t-1}+\eta_{i t}
\end{aligned}
$$

$$
\begin{aligned}
\text { AssetRisk }_{i t}= & \gamma_{0}+\gamma_{1} \operatorname{Cap}_{i t}+\gamma_{2} \text { UndRiskit } \rho_{1} \Gamma X_{t-1}+\gamma_{3} \text { Marginally Adequate Capitalisation }_{i, t-1} \\
& +\gamma_{4} \text { Undercapitalisation }_{i, t-1}+\left(1-\rho_{1}\right) \text { AssetRisk }_{i, t-1} \\
& -\rho_{2} \text { Marginally Adequate Capitalisation }_{i, t-1} \text { AssetRisk }_{i, t-1} \\
& -\rho_{3} \text { Undercapitalisation }_{i, t-1} \text { AssetRisk }_{i, t-1}+\pi_{i t},
\end{aligned}
$$

${ }^{22}$ Insurers in categories C2-C4 should face increased regulatory costs varying with the degree of their capital deficiency under the design of the RBC system. However, it is difficult to know in practice what these costs are and whether they are severe.

${ }^{23}$ Essentially the same breakdown into categories is used in Aggarwal and Jacques (2001, p. 1146).

${ }^{24}$ Note that even if $\mathrm{RBC}$ is not a good indicator of insurer risk, insurers would still be under regulatory pressure to keep the RBC ratio within acceptable bounds.

${ }^{25}$ The omitted category for the RBC regulatory pressure variables are well-capitalised insurers with $\mathrm{RBC}>3$. Insurers in category 5 are omitted from the study since they should have been seized by the regulator and most likely are in runoff.

${ }^{26}$ We thank an anonymous referee for pointing this out.

27 That is, $\left(\mathrm{Cap}_{i t}-\mathrm{Cap}_{i, t-1}\right)=\delta_{1}\left(\mathrm{Cap}_{i t}^{*}-\mathrm{Cap}_{i, t-1}\right)$ and $\delta_{1} \mathrm{Cap}_{i t}^{*}$ is $\delta_{1} A X_{t-1}$, where $X_{t-1}$ is a vector of variables assumed to be related to the capital structure. The parameter $\delta_{1}$ is subsumed within the coefficient estimates for $X_{t-1}$. 
where $\alpha_{j}, \beta_{k}$ and $\gamma_{m}$ are parameters and $A, B$ and $\Gamma$ are vectors of parameters. ${ }^{28} X_{t-1}$ is a vector of exogenous control variables assumed to determine target capital and risk. And $\tau_{i t}, \eta_{i t}$ and $\pi_{i t}$, are error terms.

Hypothesis 1 would be supported if the coefficients for the capital and risk variables are significant in Eqs. (4)-(6). More specifically, positive and significant coefficients for $\alpha_{1}$, and $\beta_{1}$, would signify that capital and underwriting risk are positively related to each other, supporting Hypothesis 1. Similarly positive and significant coefficients for $\alpha_{2}$ and $\gamma_{1}$ would indicate that asset risk and capital are positively related to each other, supporting Hypothesis 1.

Under- and marginally capitalised insurers are expected to be under pressure to decrease risk and/or increase capital. Therefore, Hypothesis $2 \mathrm{a}$ indicates that the coefficients for the under-capitalisation and marginally adequately capitalised indicators should be positive in the capital equation and/or negative in the underwriting and asset risk equations. Further the coefficient for the undercapitalisation indicator should be greater in absolute value than the coefficient for the marginally adequate capitalisation indicator, indicating that under-capitalised insurers responded more strongly to the imposition of $\mathrm{RBC}$ requirements than marginally adequately capitalised insurers.

In Eq. (4), $\delta_{1}$ is the adjustment speed of capital for well-capitalised insurers. Also, $\delta_{1}+\delta_{2}$ is the adjustment speed for capital for marginally adequately capitalised insurers, and $\delta_{1}+\delta_{3}$ is the adjustment speed of capital for under-capitalised insurers. Significant and negative coefficients for the interaction of the marginally adequate and under-capitalisation indicators with the capitalisation terms (i.e. Marginally Adequate Capitalisation $_{i, t-1} \operatorname{Cap}_{i, t-1}$ and Undercapitalisation $\left.{ }_{i, t-1} \operatorname{Cap}_{i, t-1}\right)$, with $\left|\delta_{3}\right|>\left|\delta_{2}\right|$, would support Hypothesis $2 \mathrm{~b} .{ }^{29}$ The interpretation for the sign and significance for $\lambda_{2}, \lambda_{3}, \rho_{2}$ and $\rho_{3}$ is analogous to that of $\delta_{2}, \delta_{3}$. That is, the $\lambda_{2}$ and $\lambda_{3}$ interactions are included to see if marginally adequately capitalised and under-capitalised insurers, respectively, move more quickly to their target underwriting risk levels than adequately capitalised insurers, and the $\rho_{2}$ and $\rho_{3}$ interactions are included to test whether marginally adequately capitalised and under-capitalised insurers, respectively, move towards their target asset risk levels more quickly than adequately capitalised insurers.

The system of equations (4)-(6) is estimated for 1993 (prior to the imposition of RBC) and for 1994 to 2007 . Hypothesis 3 would be supported if the coefficients for the variables involving under-capitalisation and marginally adequate capitalisation are significantly different in the 1993 estimation results compared with the 1994-2007 results.

${ }^{28}$ This equation is analogous to that in Aggarwal and Jacques (2001). Aggarwal and Jacques (2001) justify the inclusion of the capitalisation variables $\left(\mathrm{PCA}_{i}\right)$ using the same reasoning as we use for under- and marginally adequate capitalisation. Aggarwal and Jacques' (2001) capitalisation variables are not treated as endogenous, however.

${ }^{29}$ Here $\delta_{2}$ is expected to be positive if the marginally adequately capitalised insurers moved towards their target capital quicker (at the speed of $\delta_{1}+\delta_{2}$ ) than well-capitalised insurers (at the speed of $\delta_{1}$ ) because there is a negative sign before $\delta_{2}$ in Eq. 4 . 


\section{Estimation}

3SLS is used because the joint dependency between an insurer's leverage, investment and underwriting decisions means that ordinary least squares (OLS) estimation is inefficient. Further, 3SLS is a full-information estimation technique that estimates all parameters simultaneously and is preferred to two-stage least squares for this reason. That is, 3SLS incorporates the cross-equation correlations, making the parameter estimates asymptotically more efficient than two-stage least squares. Another advantage of 3SLS is that it eliminates problems associated with serial correlation in the error terms. This is because the 3SLS methodology can be interpreted as an extension of generalised least squares (GLS) to a simultaneous equation system. ${ }^{30}$ Year dummies are included in the models for the sample with years 1994-2007. ${ }^{31}$

\section{Dependent variables}

Capital equation: The specification for capital is the same as used in prior insurance and banking research: the surplus to total assets ratio. This measure is unaffected by (any anomalies in) the RBC formula.

Risk equations: Asset risk is proxied by investment in equities and real estate divided by total invested assets in some specifications, ${ }^{32}$ while in others it is proxied for by the RBC risk-weighted assets divided by invested assets. ${ }^{33}$ The rationale for using equities and real estate divided by invested assets is that these investments are considered to be relatively risky (as evidenced, e.g. by their high $\mathrm{RBC}$ risk factor loadings), and this ratio is easy to compute and cannot be manipulated. ${ }^{34}$ Risk-weighted assets have been used in prior banking research, and these are calculated by multiplying the invested asset risk factors from the RBC formula with the values for these assets for each insurer.

The use of risk-weighted assets as a proxy for investment risk poses some interesting issues. Recall that if some RBC asset factor loadings are too high while others are too low (given actual risk), insurers may be able to rearrange part of their asset portfolio

${ }^{30}$ Intriligator (1978).

31 The results without year dummies are qualitatively the same and available upon request from authors. Firm effects could not be included in the model because of the presence of dummy variables for form of organisation and group status; the latter do not vary for the firm over time.

32 Petroni and Shackelford (1996).

${ }^{33}$ This proxy is consistent with Shrieves and Dahl (1992); Jacques and Nigro (1997); and Aggarwal and Jacques (2001). Shim (2010) employs the volatility of the asset to liability ratio to measure risk. Instead, our separate proxies for asset risk and underwriting risk using RBC weights measure simultaneous changes in insurer behaviour directly and reflect how insurers responded to the new RBC requirements. Finally, insurers might only adjust their underwriting risk portfolio but not asset risk portfolio, or vice versa. Our method can better capture this possibility. Our proxies for underwriting risk incorporate the uniqueness of insurance and also address the concern of using the ratio of risk-weighted assets to total assets only as a measure of portfolio risk raised by Shim (Shim, 2010, p. 2451).

${ }^{34}$ The RBC factor for equities is 0.15 , which is higher than for all other risk classes except for the lowest rated unaffiliated bonds and preferred stock. However, the latter two assets account for an insignificant fraction of assets. 
to take advantage of this. The end result of this would be a negative relationship between actual insurer risk and capital requirements.

But, this problem cannot be detected if measures of risk rely on RBC factor loadings. Instead, if insurers rearrange their asset portfolio to exploit $\mathrm{RBC}$ anomalies, the $\mathrm{RBC}$ requirement would decline because asset risk appears to decline. Insurers would have the option of decreasing their capital base (perhaps by paying a dividend). Then there would be a positive association between capital and risk (both "apparent risk" and capital would decrease at the same time). Alternatively, insurers may decide to maintain their capital base, in which case, capital and risk would appear to be unrelated, but the RBC ratio would improve. As indicated earlier, exploitation of this type would be less likely for insurers with an RBC ratio well above the "no action" benchmark of 2. Therefore, Eqs. (4)-(6) are estimated also for insurers that are adequately capitalised since these insurers would have no incentive to manipulate the RBC formula.

In addition, the reason for using the asset $\mathrm{RBC}$ risk-weighted asset risk proxy in this study is that results prior to the imposition of $\mathrm{RBC}$ and after imposition of $\mathrm{RBC}$ are analysed. Prior to the implementation of RBC, insurers would not have had an incentive to exploit any anomalies in the RBC formula; hence, the results between the two periods studied are interesting for comparison purposes. ${ }^{35}$

Underwriting risk is measured as RBC risk-weighted net premiums written (NPW) divided by total NPW. RBC risk-weighted NPW is calculated by multiplying the NPW risk factors for each line from the RBC formula with the values for premiums by line for each insurer. Use of this measure poses the same challenges as for risk-weighted assets and the same analysis applies to observed results. As a robustness test, underwriting risk is proxied by the proportion of premiums written in risky lines (analogous to the asset risk specification based on real estate and mortgages). ${ }^{36}$ Use of risk measures such as these assumes that the RBC formula can identify risky lines (or risky assets), even if the factor loadings associated with these lines (or assets) do not completely accurately incorporate the relevant inherent risk.

\section{Control variables}

The control variables $\left(X_{i, t-1}\right)$ in the equations estimated are for organisational form, size, group status, Herfindahl index of lines of business written, geographical Herfindahl index of business written and reinsurance utilisation. These variables are explained below.

The capital and risk position of an insurer is likely to be affected by its degree of diversification. Insurers that are more diversified are expected to require less relative capital to operate and can take on relatively larger risk. Size is sometimes associated with diversification because larger insurers, in theory, should be able to achieve a better spread of risk than smaller insurers. Therefore, size, defined as the logarithm of

\footnotetext{
${ }^{35}$ However, it is also possible that insurers expected the implementation of RBC requirements and adjusted their asset and underwriting portfolios accordingly.

${ }^{36}$ Risky lines are those that have the highest NPW risk factor loadings: commercial auto liability, allied lines, earthquake, surety, theft, inland marine, fire, international, boiler and machinery, reinsurance and medical malpractice (occurrence).
} 
assets, is included in the regression models, and its expected sign is negative in the capital equation and positive in the underwriting and asset risk equations.

Insurers also diversify risk by writing across many different product lines and/or across different geographical areas. Therefore, Herfindahl indices for product mix and geographical spread are included in the model. The expected signs for the Herfindahl index variables are positive in the capital equation and negative in the underwriting and asset risk equations. That is, decreases in product mix and geographical spreads are associated with increases in the Herfindahl index and less diversification. Less diversification would be associated with higher capital requirements and less underwriting and asset risk undertaken.

Reinsurance usage is associated with increased diversification, since through reinsurance insurers can obtain a better spread of risks. ${ }^{37}$ Reinsurance usage is measured as the ratio of ceded loss reserves to the sum of direct loss reserves and assumed loss reserves. Reinsurance usage is expected to be negatively related to capital requirements and positively related to underwriting and asset risk.

An indicator variable equal to one if an insurer is a member of a group is included in the models because group insurers might have an advantage by being able to diversify risks within the group (through intra-group reinsurance) and operate with relatively lower capital levels and higher asset and underwriting risk. On the other hand, capital and risk for insurers within a group might be determined strategically at the group parent level, meaning capital and risk decisions are made differently than for insurers that are not part of a group. Thus, overall, the sign for this variable cannot be determined a priori.

Finally, an indicator variable equal to one for mutual insurers is included in the model. Agency costs and therefore capital structure may vary by organisational form. An inherent owner-policyholder conflict exists for stock insurers (but not mutual insurers) whereby owners have an incentive to increase the risk of the firm to the detriment of policyholders. But a manager-owner conflict affects stock vs mutual insurers differently because the owners of a mutual (the policyholders) do not exert much effective control over managers. ${ }^{38}$ Also, mutuals have less access to capital markets, making raising capital more difficult and costly for them. ${ }^{39}$ In summary, inherent differences in the owner-policyholder conflict and owner-manager conflict in mutual vs stock insurers and the fact that mutuals are likely to find it more difficult to raise capital may result in different capital structures for stock vs mutual insurers. Thus the sign of the indicator variable is difficult to predict a priori in the equations.

\section{Data}

The sample data consist of pooled, cross-sectional data of U.S. property-liability insurance companies included in the NAIC's database for the period 1992-2007. ${ }^{40}$

\footnotetext{
${ }^{37}$ See, for example, Cummins and Nini (2002).

${ }^{38}$ Mayers and Smith (1992 and 2005) and Mayers et al. (1997).

${ }^{39}$ Harrington and Niehaus (2002).

${ }^{40}$ The data used in the analysis was winsorised at the 5 and 95 per cent level.
} 
After 1994, data for the RBC ratio were obtained from the NAIC database. Unpublished RBC data obtained directly from the NAIC for 1992 was used in some models. ${ }^{41}$ The RBC ratios for 1992 are computed using the RBC formula for 1994. The samples used in the estimation include all insurers with positive net admitted assets, surplus and NPW. Certain specialty insurers and insurers that did not file a statement with the NAIC are excluded from the RBC database and from this study. Finally, data for two consecutive years were required for each insurer in the sample; hence, observations that did not meet this criterion were eliminated from the sample.

\section{Results}

Table 3 contains summary statistics for the 1993 sample and the sample for 1994-2007 along with the results of $t$-tests for differences in means for these samples. The results

Table 3 Summary statistics

\begin{tabular}{|c|c|c|c|}
\hline Variable & $\begin{array}{c}1993 \\
\text { sample }\end{array}$ & $\begin{array}{l}\text { 1994-2007 } \\
\text { sample }\end{array}$ & $\begin{array}{c}\text { t-tests for } \\
\text { differences } \\
\text { in means }\end{array}$ \\
\hline$(\text { Geographic Herfindahl })_{t-1}$ & 0.6045 & 0.5673 & $* * *$ \\
\hline$(\text { Lines of Business Herfindahl })_{t-1}$ & 0.5167 & 0.5403 & $* * *$ \\
\hline (Reinsurance Usage $)_{t-1}$ & 0.3550 & 0.3858 & $* * *$ \\
\hline$(\text { Group Indicator }(=1 \text { if group }))_{t-1}$ & 0.5957 & 0.6588 & $* * *$ \\
\hline (Mutual Indicator $(=1$ if mutual $))_{t-1}$ & 0.2406 & 0.1889 & $* * *$ \\
\hline $\begin{array}{l}\text { (Marginally Adequate Capitalisation ( }=1 \text { if marginally adequate } \\
\text { capitalisation) })_{t}\end{array}$ & 0.0588 & 0.0634 & \\
\hline$(\text { Undercapitalised }(=1 \text { if under-capitalised }))_{t}$ & 0.0466 & 0.0302 & $* * *$ \\
\hline $\log \left(\right.$ Assets $\left._{t-1}\right)$ & 17.4280 & 17.9990 & $* * *$ \\
\hline$(\text { Surplus/Assets })_{t-1}$ & 0.4232 & 0.4435 & $* * *$ \\
\hline$(\mathrm{RBC} \text { risk-weighted NPW/Premiums })_{t-1}$ & 0.1737 & 0.1568 & $* * *$ \\
\hline 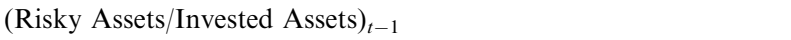 & 0.1271 & 0.1280 & \\
\hline 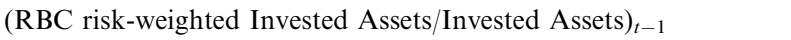 & 0.0165 & 0.0182 & $* * *$ \\
\hline (Surplus/Assets) $_{t}$ & 0.4202 & 0.4398 & $* * *$ \\
\hline$(\mathrm{RBC} \text { risk-weighted NPW/Premiums })_{t}$ & 0.1730 & 0.1564 & $* * *$ \\
\hline (Risky Assets/Invested Assets) ${ }_{t}$ & 0.1326 & 0.1283 & \\
\hline 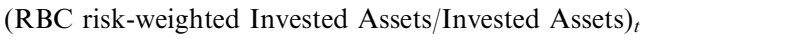 & 0.0167 & 0.0184 & $* * *$ \\
\hline$N$ & 1,887 & 26,671 & \\
\hline
\end{tabular}

Notes: $* ; * ; * * *$ significant at 10,5 and 1 per cent levels, respectively.

$\mathrm{RBC}$ risk-weighted NPW is the sum of RBC NPW risk factor for premium line $\times$ premiums in line. RBC risk-weighted Invested Assets is the sum of $\mathrm{RBC}$ asset risk factor by type $\times$ asset type. Reinsurance usage is ceded loss reserves/Total direct and assumed loss reserves. An insurer is considered to be marginally adequately capitalised if $2 \leqslant \mathrm{RBC}$ ratio $<3$ and under-capitalised if $\mathrm{RBC}$ ratio $<2$. Risky Invested Assets are the sum of stock and real estate investments.

${ }^{41}$ Prior to 1994, an insurer's RBC ratio was not published; however, data for 1992 were available from the NAIC. Unfortunately, the NAIC did not have RBC ratio data for 1991 and 1993. 
indicate that many significant differences exist between the two samples. ${ }^{42}$ Notably, the proportion of the sample that was under-capitalised in 1993 is significantly larger than in the 1994-2007 period. Underwriting risk (proxied by the (RBC risk-weighted NPW/Premiums) in year $t$ and $t-1$ ) is greater in 1993 compared with the 1994-2007 period. Also, the geographic Herfindahl, and the proportion of mutuals are significantly greater in the 1993 period compared with the 1994-2007 period. All other variables are significantly lower in the 1993 period, except for the marginally adequate capitalisation indicator, and (Risky Assets/Invested Assets) in years $t$ and $t-1$, which are not significantly different between the two periods.

Tables 4-7 contain the 3SLS regression results. Table 4 uses (RBC risk-weighted Invested Asset/Invested Assets) ${ }_{t}$ as the risk measure for asset risk, while Table 5 uses the alternative measure for asset risk, (Risky Invested Assets/ Invested Assets). Tables 6 and 7 are analogous to Tables 4 and 5 except that the analyses are carried out for insurers that are well above the "no action" threshold for RBC, that is, only insurers with RBC greater than 3 are used in the analysis for Tables 6 and 7. The coefficients for the year dummies for the 1994-2007 samples have been suppressed in the results for space reasons.

Hypothesis 1 states that insurers' risk and capital should be positively related to each other. The results for 1994-2007 in Table 4 bear this out for underwriting risk. In these regressions, the coefficient for (Surplus/Assets) $t_{t}$ is positive and significant in the (RBC risk-weighted NPW/Premiums) ${ }_{t}$ equation and the coefficient for (RBC riskweighted NPW/Premiums) ${ }_{t}$ is positive and significant in the (Surplus/Assets) ${ }_{t}$ equation. Based on the surplus/assets equation in Table 4, an increase of one standard deviation in the underwriting risk variable (0.0525829) leads to an increase in the capital level of 0.0049 (or 3.1 per cent) for 1994-2007. Similarly, an increase in one standard deviation in the investment risk variable (0.0200629) leads to an increase in the capital level of 0.0020 (or 10.9 per cent) for 1994-2007. In Table 5 the same results exist. Also, the results in Tables 4 and 5 for 1994-2007 are consistent with Hypothesis 1 with respect to investment risk, that is, the coefficient for the (RBC risk-weighted Invested Asset/Assets) ${ }_{t}$ is positive and significant in the (Surplus/Assets) ${ }_{t}$ equation and vice versa.

As indicated earlier, a positive or insignificant relationship between capital and risk can arise from exploitation of the $\mathrm{RBC}$ formula. This exploitation would most likely occur, if it occurred at all, for insurers close to the "no action" threshold or in the action level categories. Therefore, the analyses are carried out also for insurers with $\mathrm{RBC}$ ratios well above the threshold, that is, for insurers with $\mathrm{RBC}$ ratios greater than three. And these results are in Tables 6 and 7. The results in Tables 6 and 7 confirm the findings of Tables 4 and 5 , that is, the capital and risk variables are significantly and positively related to each other across the three equations. Thus Hypothesis 1 is strongly supported for 1994-2007.

All these results do not consistently hold for 1993, as the coefficient for (RBC risk-weighted NPW/Surplus) ${ }_{t}$ is insignificant in the (Surplus/Assets) $t_{t}$ equation in

\footnotetext{
${ }^{42}$ The results of the Wilcoxon test for the difference in medians are virtually the same as for the differences in means.
} 
Table 4 Three-stage least squares results (RBC risk-weighted Invested Asset/Invested Assets) $t_{t}$ used as dependent variable (all insurers)

\begin{tabular}{|c|c|c|c|c|c|c|}
\hline \multirow{2}{*}{$\frac{\text { Results for year }(s)}{\text { Dependent variable }}$} & \multicolumn{3}{|c|}{1993} & \multicolumn{3}{|c|}{ 1994-2007 with year dummies } \\
\hline & $\begin{array}{l}\text { (Surplus/ } \\
\text { Assets) }\end{array}$ & $\begin{array}{c}(R B C \\
\text { risk-weighted } \\
\text { NPW/ } \\
\text { Premium) }\end{array}$ & $\begin{array}{c}\text { (RBC risk-weighted } \\
\text { Invested Asset/ } \\
\text { Invested Assets) }\end{array}$ & $\begin{array}{l}\text { (Surplus/ } \\
\text { Assets) }\end{array}$ & $\begin{array}{c}\text { (RBC risk- } \\
\text { weighted } \mathrm{NPW/} \\
\text { Premium) }\end{array}$ & $\begin{array}{c}\text { (RBC risk-weighted } \\
\text { Invested Asset/Invested } \\
\text { Assets) }\end{array}$ \\
\hline \multicolumn{7}{|l|}{ Independent variables } \\
\hline Intercept & $\begin{array}{l}0.040664 \\
(1.428)\end{array}$ & $\begin{array}{l}0.016468 * * \\
(2.307)\end{array}$ & $\begin{array}{l}-0.005640^{*} \\
(-1.932)\end{array}$ & $\begin{array}{l}0.070290^{* * *} \\
(8.579)\end{array}$ & $\begin{array}{l}0.017533^{* * *} \\
(8.254)\end{array}$ & $\begin{array}{l}-0.004413^{* * *} \\
(-5.793)\end{array}$ \\
\hline$(\text { Geographic Herfindahl })_{t-1}$ & $\begin{array}{l}0.001483 \\
(0.261)\end{array}$ & $\begin{array}{l}0.000497 \\
(0.354)\end{array}$ & $\begin{array}{l}0.000216 \\
(0.370)\end{array}$ & $\begin{array}{l}-0.002043 \\
(-1.347)\end{array}$ & $\begin{array}{l}-0.002531 \text { *** } \\
(-6.555)\end{array}$ & $\begin{array}{l}0.000254^{*} \\
(1.812)\end{array}$ \\
\hline (Lines of Business Herfindahl) $)_{t-1}$ & $\begin{array}{l}-0.00223 \\
(-0.298)\end{array}$ & $\begin{array}{l}-0.006905^{* * *} \\
(-3.712)\end{array}$ & $\begin{array}{l}0.000437 \\
(0.570)\end{array}$ & $\begin{array}{l}-0.00219 \\
(-1.106)\end{array}$ & $\begin{array}{l}-0.009174^{* * *} \\
(-18.320)\end{array}$ & $\begin{array}{l}0.000056 \\
(0.307)\end{array}$ \\
\hline (Reinsurance Usage $)_{t-1}$ & $\begin{array}{l}-0.010441 \\
(-1.520)\end{array}$ & $\begin{array}{l}-0.004048^{* *} \\
(-2.380)\end{array}$ & $\begin{array}{l}-0.000708 \\
(-1.004)\end{array}$ & $\begin{array}{l}-0.009534 * * * \\
(-5.297)\end{array}$ & $\begin{array}{l}-0.000336 \\
(-0.732)\end{array}$ & $\begin{array}{l}-0.000754 * * * \\
(-4.546)\end{array}$ \\
\hline (Group Indicator $(=1$ if group $))_{t-1}$ & $\begin{array}{l}-0.0064 \\
(-1.351)\end{array}$ & $\begin{array}{l}-0.002586 * * \\
(-2.212)\end{array}$ & $\begin{array}{l}-0.000281 \\
(-0.578)\end{array}$ & $\begin{array}{l}0.002968^{* *} \\
(2.279)\end{array}$ & $\begin{array}{l}0.000184 \\
(0.554)\end{array}$ & $\begin{array}{l}-0.000142 \\
(-1.177)\end{array}$ \\
\hline (Mutual Indicator $(=1$ if mutual $))_{t-1}$ & $\begin{array}{l}0.003841 \\
(0.792)\end{array}$ & $\begin{array}{l}-0.000675 \\
(-0.562)\end{array}$ & $\begin{array}{l}0.001004^{* *} \\
(2.025)\end{array}$ & $\begin{array}{l}0.005057^{* * *} \\
(3.526)\end{array}$ & $\begin{array}{l}0.000233 \\
(0.636)\end{array}$ & $\begin{array}{l}0.000824^{* * *} \\
(6.249)\end{array}$ \\
\hline $\log \left(\right.$ Assets $\left._{t-1}\right)$ & $\begin{array}{l}-0.000149 \\
(-0.107)\end{array}$ & $\begin{array}{l}0.000177 \\
(0.517)\end{array}$ & $\begin{array}{l}0.000295^{* *} \\
(2.095)\end{array}$ & $\begin{array}{l}-0.001684 * * * \\
(-4.426)\end{array}$ & $\begin{array}{l}-0.000432 * * * \\
(-4.423)\end{array}$ & $\begin{array}{l}0.000343^{* * *} \\
(9.804)\end{array}$ \\
\hline (RBC risk-weighted NPW/Surplus) ${ }_{t}$ & $\begin{array}{l}-0.001191 \\
(-0.034)\end{array}$ & & $\begin{array}{l}0.003517 \\
(0.967)\end{array}$ & $\begin{array}{l}0.094015^{* * *} \\
(8.049)\end{array}$ & & $\begin{array}{l}-0.001095 \\
(-1.007)\end{array}$ \\
\hline (RBC risk-weighted Invested Assets/Invested Assets) $t_{t}$ & $\begin{array}{l}0.260540 * * \\
(2.205)\end{array}$ & $\begin{array}{l}-0.029025 \\
(-0.987)\end{array}$ & & $\begin{array}{l}0.197554 * * * \\
(6.350)\end{array}$ & $\begin{array}{l}0.002895 \\
(0.363)\end{array}$ & \\
\hline$(\text { Surplus/Assets) })_{t-1}$ & $\begin{array}{l}0.911436 * * * \\
(79.922)\end{array}$ & & & $\begin{array}{l}0.878315^{* * *} \\
(266.818)\end{array}$ & & \\
\hline $\begin{array}{l}\text { (Marginally Adequate Capitalisation } \\
(=1 \text { if marginally adequate capitalisation }))_{t-1}\end{array}$ & $\begin{array}{l}0.005185 \\
(0.207)\end{array}$ & $\begin{array}{l}-0.008551 * * \\
(-1.979)\end{array}$ & $\begin{array}{l}0.000608 \\
(0.552)\end{array}$ & $\begin{array}{l}0.002208 \\
(0.373)\end{array}$ & $\begin{array}{l}0.016912^{* * * *} \\
(11.064)\end{array}$ & $\begin{array}{l}0.000488^{*} \\
(1.803)\end{array}$ \\
\hline$(\text { Undercapitalised }(=1 \text { if under-capitalised }))_{t-1}$ & $\begin{array}{l}-0.008133 \\
(-0.602)\end{array}$ & $\begin{array}{l}0.020662 * * * \\
(4.470)\end{array}$ & $\begin{array}{l}0.001187 \\
(0.965)\end{array}$ & $\begin{array}{l}-0.005007 \\
(-1.213)\end{array}$ & $\begin{array}{l}0.027195^{* * *} \\
(17.401)\end{array}$ & $\begin{array}{l}0.001245^{* * *} \\
(3.410)\end{array}$ \\
\hline $\begin{array}{l}\text { Surplus/Assets) })_{t-1} * \text { (Marginally Adequate } \\
\text { Capitalisation }(=1 \text { if marginally adequate } \\
\text { capitalisation }))_{t-1}\end{array}$ & $\begin{array}{l}-0.047729 \\
(-0.456)\end{array}$ & & & $\begin{array}{l}0.00393 \\
(0.201)\end{array}$ & & \\
\hline
\end{tabular}


(Surplus/Assets) $)_{t-1} *($ Undercapitalised $(=1$ if under-capitalised $))_{t-1}$

(Surplus/Assets)

(RBC risk-weighted NPW/Premiums) ${ }_{t-1}$

(RBC risk-weighted NPW/Premiums) $t_{t-1}$ *

(Marginally Adequate Capitalisation

(=1 if marginally adequate capitalisation) $)_{t-1}$

(RBC risk-weighted NPW/Premiums) $)_{t-1}{ }^{*}$

(Undercapitalised ( $=1$ if under-capitalised) $)_{t-1}$

(RBC risk-weighted Invested Assets/Invested Assets) ${ }_{t-1}$

(RBC risk-weighted Invested Assets/Invested Assets) $)_{t-1}$ * (Marginally Adequate Capitalisation (=1 if marginally adequate capitalisation) $)_{t-1}$

(RBC risk-weighted Invested Assets/Invested

Assets $)_{t-1} *(\text { Undercapitalised }(=1 \text { if under-capitalised }))_{t-1}$ $R$-squared

Number of observations.

\begin{tabular}{ccc} 
& 1993 & \\
\hline (Surplus) & (RBC & (RBC risk-weighted \\
Assets) & risk-weighted & Invested Asset/ \\
& NPW/ & Invested Assets) \\
& Premium) &
\end{tabular}

\begin{tabular}{|c|c|c|}
\hline \multicolumn{3}{|c|}{ 1994-2007 with year dummies } \\
\hline $\begin{array}{c}\text { (Surplus/ } \\
\text { Assets) }\end{array}$ & $\begin{array}{l}\text { (RBC risk- } \\
\text { weighted NPW/ } \\
\text { Premium) }\end{array}$ & $\begin{array}{c}\text { (RBC risk-weighted } \\
\text { Invested Asset/Invested } \\
\text { Assets) }\end{array}$ \\
\hline
\end{tabular}

$-0.024898$

$(-0.432)$

$0.005316^{*}$
$(1.721)$
$0.907042 * * *$
$(86.174)$
$0.069820 * * *$
$(3.366)$

$-0.058739 * * *$
$(-3.225)$

$\begin{array}{cc} & -0.015032 \\ & (-1.080)\end{array}$

(2.707)

$-0.01503$

$0.008043^{*}$

(8.668)

$0.002095 * * *$

0.912235

$-0.100432$

$(-11.469)$

$-0.105942^{* * *}$

$(-13.477)$

$0.907695^{* * *}$
$(79.060)$
$-0.139938^{* * *}$
$(-2.906)$

0.083646
$(1.461)$
0.814
1,887

$0.913011^{* * *}$

(336.860)

$-0.046186^{* * *}$

$-0.143709^{* * *}$

$(-8.846)$

0.856

Notes: * **,*** significant at 10,5 and 1 per cent levels, respectively. $z$-statistics in parentheses below coefficients.

RBC risk-weighted NPW is the sum of RBC NPW risk factor for premium line $\times$ premiums in line. RBC risk-weighted Invested Assets is the sum of RBC asset risk factor by type $\times$ asset type. Reinsurance usage is ceded loss reserves/Total direct and assumed loss reserves. An insurer is considered to be marginally adequately capitalised if $2 \leqslant \mathrm{RBC}$ ratio $<3$ and under-capitalised if $\mathrm{RBC}$ ratio $<2$. 
Table 5 Three-stage least squares results (Risky Invested Assets/Invested Assets) $t$ used as dependent variable (all insurers)

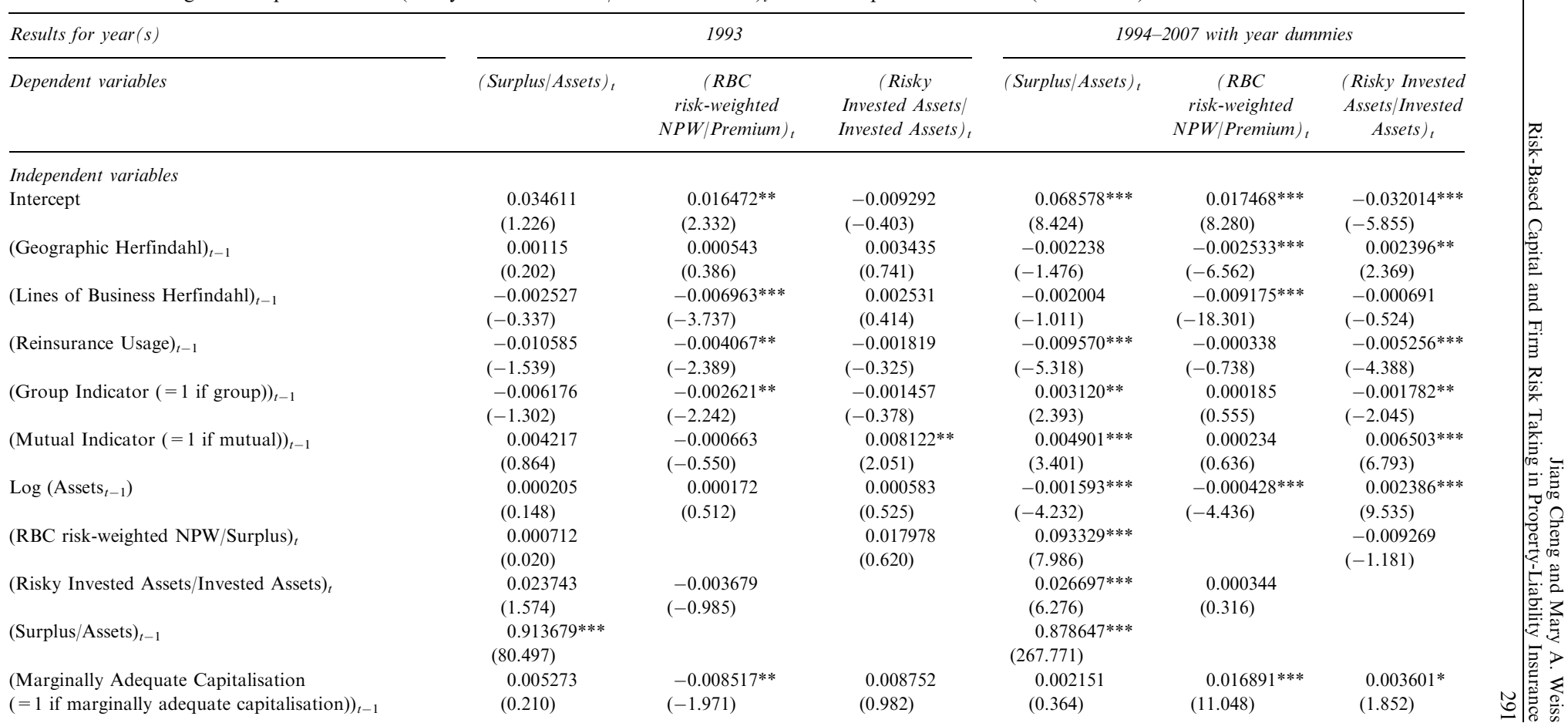




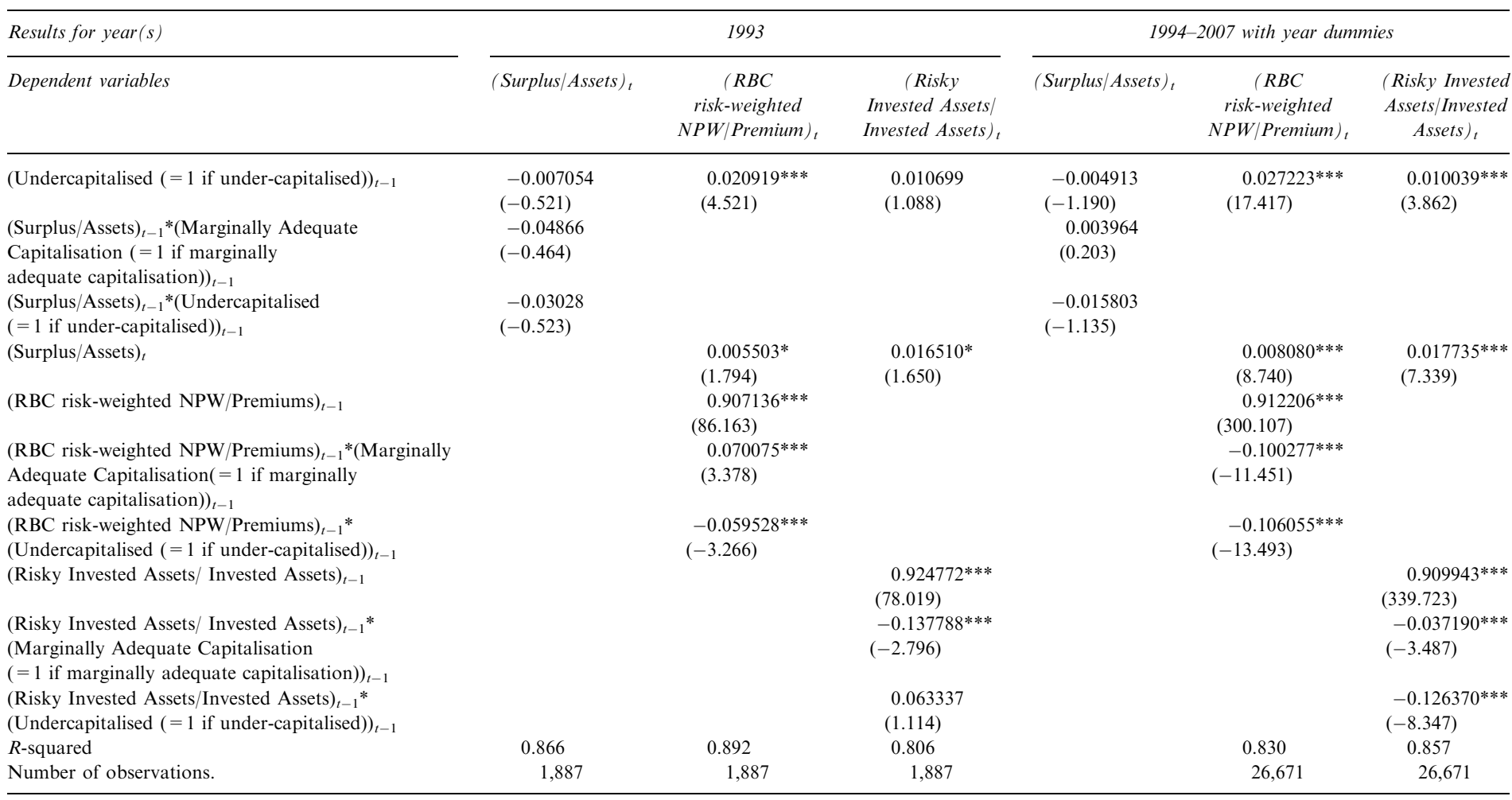

Notes: *; **;*** significant at 10,5 and 1 per cent levels, respectively. $z$-statistics in parentheses below coefficients.

RBC risk-weighted NPW is the sum of RBC NPW risk factor for premium line $\times$ premiums in line. Reinsurance usage is ceded loss reserves/Total direct and assumed loss reserves. An insurer is considered to be marginally adequately capitalised if $2 \leqslant \mathrm{RBC}$ ratio $<3$ and under-capitalised if $\mathrm{RBC}$ ratio $<2$. Risky Invested Assets are the sum of stock and real estate investments. 
Table 6 Three-stage least squares results (RBC risk-weighted Invested Asset/Invested Assets) $t_{t}$ used as dependent variable (insurers with RBC ratio greater than 3 )

\begin{tabular}{|c|c|c|c|c|c|c|}
\hline \multirow{2}{*}{$\frac{\text { Results for year }(s)}{\text { Dependent variables }}$} & \multicolumn{3}{|c|}{1993} & \multicolumn{3}{|c|}{ 1994-2007 with year dummies } \\
\hline & (Surplus/Assets) ${ }_{t}$ & $\begin{array}{c}(R B C \\
\text { risk-weighted } \\
\text { NPW/Premium })_{t}\end{array}$ & $\begin{array}{c}(R B C \\
\text { risk-weighted } \\
\text { Invested } \\
\text { Asset/Invested } \\
\text { Assets) })_{t}\end{array}$ & (Surplus/Assets) ${ }_{t}$ & $\begin{array}{c}(R B C \\
\text { risk-weighted } \\
\text { NPW/Premium })_{t}\end{array}$ & $\begin{array}{c}(R B C \\
\text { risk-weighted } \\
\text { Invested } \\
\text { Asset/Invested } \\
\text { Assets) })_{t}\end{array}$ \\
\hline \multicolumn{7}{|l|}{ Independent variables } \\
\hline Intercept & $\begin{array}{l}0.024802 \\
(0.822)\end{array}$ & $\begin{array}{l}0.016700^{* * * *} \\
(2.776)\end{array}$ & $\begin{array}{l}-0.007593 * * \\
(-2.507)\end{array}$ & $\begin{array}{l}0.055451 * * * \\
(6.411)\end{array}$ & $\begin{array}{l}0.019096 * * * \\
(10.363)\end{array}$ & $\begin{array}{l}-0.004209 * * * \\
(-5.234)\end{array}$ \\
\hline (Lines of Business Herfindahl $)_{t-1}$ & $\begin{array}{l}0.001236 \\
(0.161)\end{array}$ & $\begin{array}{l}-0.007283^{* * *} \\
(-4.742)\end{array}$ & $\begin{array}{l}0.000309 \\
(0.400)\end{array}$ & $\begin{array}{l}0.000106 \\
(0.052)\end{array}$ & $\begin{array}{l}-0.007271^{* * *} \\
(-16.848)\end{array}$ & $\begin{array}{l}0.000125 \\
(0.658)\end{array}$ \\
\hline (Reinsurance Usage $)_{t-1}$ & $\begin{array}{l}-0.015002 * * \\
(-2.145)\end{array}$ & $\begin{array}{l}-0.003282^{* *} \\
(-2.353)\end{array}$ & $\begin{array}{l}-0.000636 \\
(-0.905)\end{array}$ & $\begin{array}{l}-0.009643 * * * \\
(-5.156)\end{array}$ & $\begin{array}{l}-0.000034 \\
(-0.085)\end{array}$ & $\begin{array}{l}-0.000649 * * * \\
(-3.758)\end{array}$ \\
\hline (Group Indicator ( $=1$ if group) $)_{t-1}$ & $\begin{array}{l}-0.009085^{*} \\
(-1.867)\end{array}$ & $\begin{array}{l}-0.002322 * * \\
(-2.406)\end{array}$ & $\begin{array}{l}-0.00068 \\
(-1.411)\end{array}$ & $\begin{array}{l}0.002716^{* *} \\
(2.008)\end{array}$ & $\begin{array}{l}-0.0001 \\
(-0.349)\end{array}$ & $\begin{array}{l}-0.000240^{*} \\
(-1.914)\end{array}$ \\
\hline (Mutual Indicator $(=1 \text { if mutual) })_{t-1}$ & $\begin{array}{l}0.003216 \\
(0.644)\end{array}$ & $\begin{array}{l}-0.001188 \\
(-1.193)\end{array}$ & $\begin{array}{l}0.000941 * \\
(1.881)\end{array}$ & $\begin{array}{l}0.005596 * * * \\
(3.815)\end{array}$ & $\begin{array}{l}0.000346 \\
(1.109)\end{array}$ & $\begin{array}{l}0.000795 * * * \\
(5.883)\end{array}$ \\
\hline $\log \left(\right.$ Assets $\left._{t-1}\right)$ & $\begin{array}{l}0.000162 \\
(0.111)\end{array}$ & $\begin{array}{l}0.000115 \\
(0.397)\end{array}$ & $\begin{array}{l}0.000436 * * * \\
(3.014)\end{array}$ & $\begin{array}{l}-0.001181 * * * \\
(-2.960)\end{array}$ & $\begin{array}{l}-0.000465^{* * *} \\
(-5.461)\end{array}$ & $\begin{array}{l}0.000340 * * * \\
(9.244)\end{array}$ \\
\hline (RBC risk-weighted NPW/Surplus)t & $\begin{array}{l}0.094990 * * \\
(2.097)\end{array}$ & & $\begin{array}{l}0.000674 \\
(0.147)\end{array}$ & $\begin{array}{l}0.123982 * * * \\
(9.714)\end{array}$ & & $\begin{array}{l}-0.001314 \\
(-1.103)\end{array}$ \\
\hline ( $\mathrm{RBC}$ risk-weighted Invested & $0.266337 * *$ & -0.007791 & & $0.198772 * * *$ & 0.00287 & \\
\hline Assets/Invested Assets) ${ }_{t}$ & $(2.219)$ & $(-0.323)$ & & $(6.274)$ & $(0.423)$ & \\
\hline (Surplus/Assets) $_{t-1}$ & $\begin{array}{l}0.907895^{* * *} \\
(80.005)\end{array}$ & & & $\begin{array}{l}0.877377 * * * \\
(266.535)\end{array}$ & & \\
\hline (Surplus/Assets) ${ }_{t}$ & & $\begin{array}{l}0.005507^{* *} \\
(2.216)\end{array}$ & $\begin{array}{l}0.003193 * * \\
(2.562)\end{array}$ & & $\begin{array}{l}0.006826^{* * *} \\
(8.612)\end{array}$ & $\begin{array}{l}0.001913 * * * \\
(5.542)\end{array}$ \\
\hline ( $\mathrm{RBC}$ risk-weighted & & $0.908358 * * *$ & & & $0.914898 * * *$ & \\
\hline $\mathrm{NPW} /$ Premiums $)_{t-1}$ & & $(110.370)$ & & & $(365.036)$ & \\
\hline ( $\mathrm{RBC}$ risk weighted Invested & & & $0.906727 * * *$ & & & $0.914108 * * *$ \\
\hline Assets/ Invested Assets) ${ }_{t-1}$ & & & $(82.188)$ & & & $(339.174)$ \\
\hline$R$-squared & 0.866 & 0.889 & 0.834 & 0.817 & 0.869 & 0.863 \\
\hline Number of observations. & 1,688 & 1,688 & 1,688 & 24,174 & 24,174 & 24,174 \\
\hline
\end{tabular}

Notes: $* * * ; * *$ significant at 10,5 and 1 per cent levels, respectively. $z$-statistics in parentheses below coefficients.

RBC risk-weighted NPW is the sum of RBC NPW risk factor for premium line $\times$ premiums in line. RBC risk-weighted Invested Assets is the sum of RBC asset risk factor by type $\times$ asset type. Reinsurance usage is ceded loss reserves/Total direct and assumed loss reserves. An insurer is considered to be marginally adequately capitalised if $2 \leqslant \mathrm{RBC}$ ratio $<3$ and under-capitalised if $\mathrm{RBC}$ ratio $<2$. 
Table 7 Three-stage least squares results (Risky Invested Assets/Invested Assets) $t_{t}$ used as dependent variable (insurers with RBC ratio greater than 3)

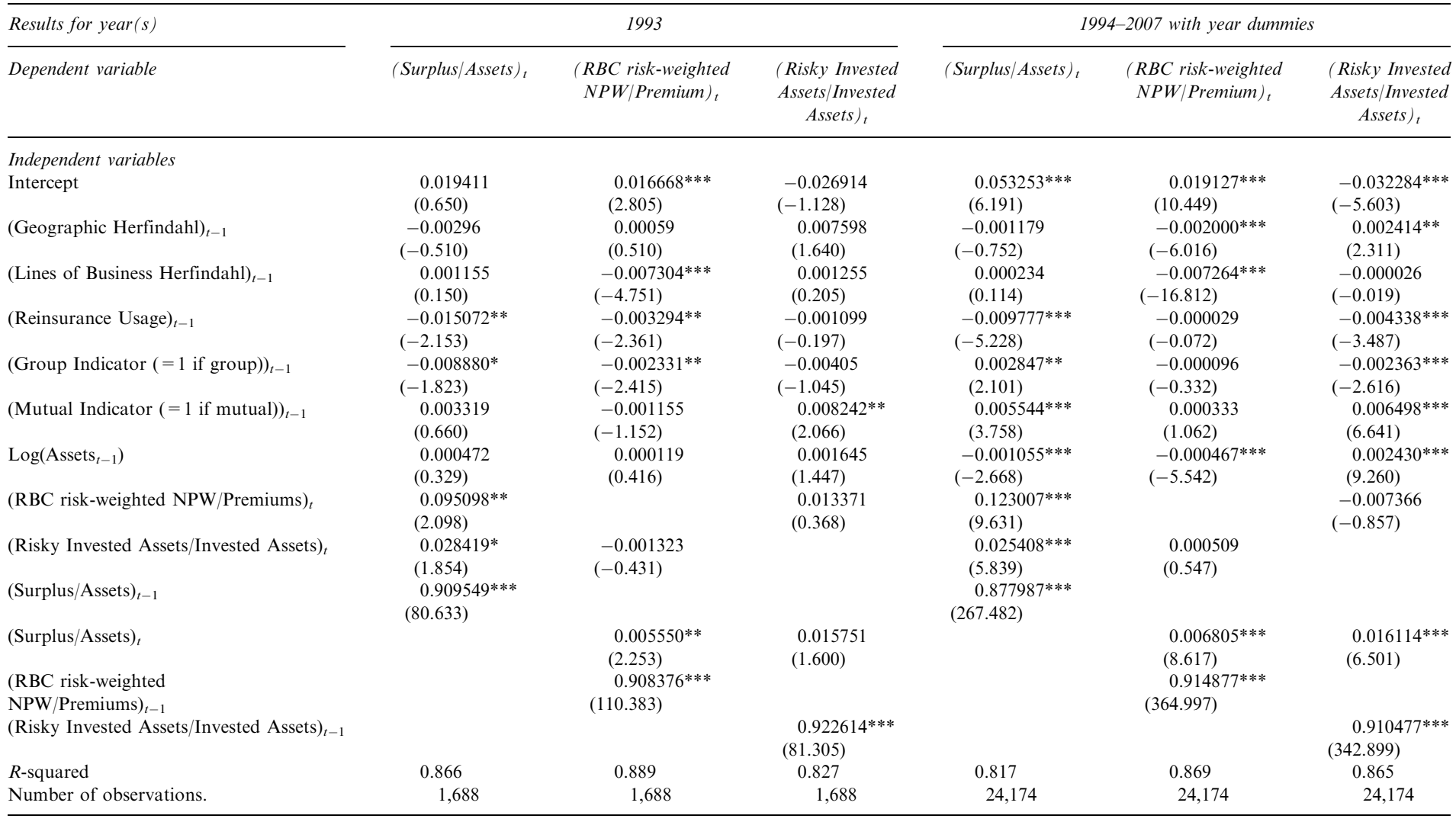

Notes: $* * * ; * *$ significant at 10,5 and 1 per cent levels, respectively. $z$-statistics in parentheses below coefficients.

$\mathrm{RBC}$ risk-weighted NPW is the sum of RBC NPW risk factor for premium line $\times$ premiums in line. Reinsurance usage is ceded loss reserves/Total direct and assumed loss reserves. An insurer is considered to be marginally adequately capitalised if $2 \leqslant \mathrm{RBC}$ ratio $<3$ and under-capitalised if $\mathrm{RBC}$ ratio $<2$. Risky Invested Assets are the sum of stock and real estate investments. 
Tables 4 and 5. This result suggests that in 1993, underwriting risk and capitalisation were not significantly related to each other. In Table 7, the coefficient for (Surplus/ Asset) $_{t}$ is insignificant in the (Risky Invested Assets/Invested Assets) ${ }_{t}$ equation, indicating that investment risk and capitalisation are unrelated. The inconclusive results for 1993 are similar to results found in prior studies for years before the imposition of new banking capital requirements. ${ }^{43}$

Robustness tests were carried out in which the proportion of premiums written in risky lines is substituted for (RBC risk-weighted NPW/Premiums); and the results are in Tables A1-A4. The results generally support the significant and positive relationships between capital and underwriting and asset risk for the 1994-2007 period in Tables 4-7. Similar to the results in Tables 4-7, a positive relationship between capital and asset risk exists, but the relationship between capital and underwriting risk tends to be insignificant in the 1993 results.

The coefficients for (Surplus/Assets) ${ }_{t-1}$, (RBC risk-weighted NPW/Premiums) ${ }_{t-1}$, (RBC risk-weighted Invested Assets/Invested Assets) ${ }_{t-1}$ and (Risky Invested Assets/ Invested Assets) $)_{t-1}$ can be interpreted as the speed of adjustment towards target ratios for capital, underwriting risk and asset risk, respectively, according to the model specification. In Tables 4 and 7 all the speeds of adjustment variables are significant, and the coefficients are all between zero and one. The speed of adjustment results for well-capitalised insurers in Tables 4 and 5 are approximately 0.09 in the asset and underwriting risk equations and 0.09 to 0.12 in the capital equation. ${ }^{44}$ These speeds of adjustment are very low compared with nonfinancial firms. ${ }^{45}$

For the period 1994-2007, the coefficients for the indicator variables for marginally adequately capitalised insurers and under-capitalised insurers are positive and significant in the (RBC risk-weighted NPW/Premiums) $)_{t}$ and (RBC risk-weighted Invested Asset/Invested Assets) $)_{t}$ equations in Table 4. The coefficients for these variables in the (Surplus/Asset) ${ }_{t}$ equation are insignificant. Contrary to Hypothesis $2 \mathrm{a}$, this result signifies that insurers classified as under- or marginally adequately capitalised in the prior year had higher underwriting and investment risk than adequately capitalised insurers in the current year, with no difference in capital ratios. Consistent with Hypothesis 2a, however, the absolute value of the coefficients for under-capitalised insurers is greater than for marginally adequately capitalised insurers, even if the signs of the coefficients are the reverse of what was expected. The results in Table 5 confirm these findings for the period 1994-2007.

The reasons for these results are not clear. Perhaps these insurers, because of their degree of capitalisation, had trouble raising capital in the market accounting for the insignificant effect in the (Surplus/Asset) ${ }_{t}$ equation, and the results for underwriting and investment risk would be consistent with a "go for broke" attitude for these insurers. In any event, it appears that RBC requirements did not pressure under- or

\footnotetext{
${ }^{43}$ See, for example, Aggarwal and Jacques (2001).

${ }^{44}$ Recall that the coefficients for the variables mentioned must be subtracted from one to obtain the speed of adjustment. For example, the coefficient for $\mathrm{Cap}_{i, t-1}$ is $\left(1-\delta_{1}\right)$.

${ }^{45}$ See, for example, Flannery and Rangan (2006); Huang and Ritter (2009); Ovtchinnikov (2010); Cheng and Weiss (2012b).
} 
marginally adequately capitalised insurers to increase capital or reduce risk from the prior year.

The results for 1994-2007 are not consistent with those for 1993 in Table 4. For the 1993 sample, marginally adequately capitalised insurers significantly decreased their underwriting risk from the prior year, as signified by the negative and significant coefficient for this variable in the 1993 results. However, under-capitalised insurers increased underwriting risk, consistent with the results for 1994-2007. The same results apply to Table 5 for 1993 .

Hypothesis $2 \mathrm{~b}$ indicates that marginally adequately capitalised insurers and undercapitalised insurers move towards their target capital and risk levels more quickly than adequately capitalised insurers, and the results in Table 4 for 1994-2007 bear this out for underwriting risk and investment risk. ${ }^{46}$ That is the coefficients for the interaction variables for under- and marginally adequate capitalisation with (RBC risk-weighted $\mathrm{NPW} /$ Premiums) $)_{t-1}$ and (RBC risk-weighted Invested Assets/Invested Assets) $t_{t-1}$ are negative and significant in the (RBC risk-weighted NPW/Premiums) $t$ and (RBC riskweighted Invested Asset/Invested Assets) ${ }_{t}$ equations. The coefficients for the interaction terms in the (Surplus/Assets) ${ }_{t}$ equation are insignificant. Thus Hypothesis $2 \mathrm{~b}$ is partly supported for 1994-2007 in the results in Table 4. Table 5 has similar results for 1994 to 2007. Thus, overall, under- and marginally adequately capitalised insurers moved towards their target underwriting risk and investment risk ratios faster than adequately capitalised insurers.

Further, under-capitalised insurers moved more quickly towards their target underwriting and asset risk ratios than marginally adequately capitalised insurers. That is the absolute value of the coefficients for the interaction variables are larger for undercapitalised insurers than for marginally adequately capitalised insurers. For example in the invested assets equation, the coefficient for the interaction of the undercapitalisation indicator variable is -0.1437 , while the coefficient for the marginally adequately capitalised indicator interacted with (RBC risk-weighted Invested Assets/ Invested Assets $)_{t-1}$ is -0.0462 . $^{47}$

The results for 1993 in Tables 4 and 5 are somewhat similar to the results for 1994-2007 except that the coefficient for the interaction term with the undercapitalisation indicator is insignificant in the invested assets equation. Also the coefficient for the interaction of underwriting risk ratios with the marginally adequately capitalised indicator variable is positive and significant, signifying that in 1993, insurers that were marginally adequately capitalised in 1992 were slower to move towards their target underwriting risk ratio than under-capitalised or adequately capitalised insurers. Thus the results for Hypothesis $2 \mathrm{~b}$ are mixed for the 1993 results in Tables 4 and 5.

\footnotetext{
${ }^{46}$ Recall that the expected sign for these variables is negative in Eqs. (4)-(6).

${ }^{47}$ The results observed for marginally adequately capitalised and under-capitalised insurers do not appear to be due to multicollinearity, that is, when the indicator variables for marginally adequately capitalised and under-capitalised insurers are omitted from the equation, the interaction terms with the indicator variables for under- and marginally adequately capitalised insurers are similar to the results reported here.
} 
Overall, the results with respect to the under-capitalisation and marginally adequate capitalisation indicator variables for asset and underwriting risk are at odds with the results for the interaction of variables involving the under-capitalisation and marginally adequate capitalisation variables for 1994-2007. To determine the net effect of these variables on the asset and underwriting risk ratios, the impact of the variables just mentioned are evaluated at the mean for these respective insurers. ${ }^{48}$ For marginally adequately capitalised insurers at the mean, the underwriting risk ratio is higher by approximately 1 per cent. Similarly, the net effect of the marginally adequate capitalisation indicator variable and the interaction of the marginally adequate insurer capitalisation indicator variable with the prior year asset risk ratio is -1.698 per cent. ${ }^{49}$ Thus, for marginally adequately capitalised insurers at the mean, underwriting risk increased by about 1 per cent and asset risk decreased by a net amount of 1.698 per cent.

The same analysis can be conducted for the 1994-2007 period with the undercapitalisation indicator variable and the interaction of the under-capitalisation variable with the prior year underwriting risk and asset risk ratios. ${ }^{50}$ The net impact at the mean for the 1994-2007 period is 0.00866 or 4.9 per cent of the mean (RBC riskweighted NPW/Surplus). That is, the underwriting risk ratio was higher by 4.9 per cent for under-capitalised insurers at the mean over the period 1994-2007. The net impact of the variables involving the (RBC risk-weighted Invested Assets/Assets) ${ }_{t}$ is -0.0005624 , which represents -0.464 per cent of (RBC risk-weighted Invested Asset/ Assets) ${ }_{t}$ for under-capitalised insurers. ${ }^{51}$

Throughout the discussion of the results, differences between the results for 1993 and 1994-2007 have been noted. For example, the coefficients for marginally

${ }^{48}$ That is, for marginally adequately capitalised insurers at the mean, the underwriting risk ratio is higher by 0.016912 (i.e. the coefficient for the marginally adequately capitalised indicator in Table 4) for 19942007. The impact of the marginally adequately capitalised indicator variable interacted with the prior year underwriting risk ratio at the mean is -0.016514 (i.e. the coefficient for the interaction term $(-0.100432)$ multiplied with the sample mean for the prior year underwriting risk ratio of marginally adequately capitalised insurers (0.1644297)). Thus the net effect on underwriting risk is to increase the underwriting risk ratio (i.e. $0.016912-0.016514>0$ ).

49 That is, the impact of the marginally adequate capitalisation indicator variable on the asset risk ratio is 0.000488 , signifying that the asset risk ratio is higher by 0.000488 for marginally adequately capitalised insurers. The impact at the mean for the interaction of the marginally adequate insurer capitalisation indicator variable with the prior year asset risk ratio is 0.0007675 (i.e. $-0.046186 \times 0.0166168$, where -0.046186 is the coefficient for the indicator variable and 0.0166168 is the mean for (RBC riskweighted Invested Asset/Assets) ${ }_{t-1}$ ) for marginally adequately capitalised insurers. The net impact on (RBC risk-weighted Invested Asset/Assets) $)_{t}$ is $0.000488-0.0007675=-0.0002795$, and this amount represents -1.698 per cent of (RBC risk-weighted Invested Asset/Assets) $t_{t}$ (i.e. $-0.0002795 / 0.0164059$ ).

${ }^{50}$ The underwriting risk ratio is higher by 0.027195 for under-capitalised insurers, while the impact of the under-capitalisation indicator interacted with the sample mean of (RBC risk-weighted NPW/ Premiums) $t_{t-1}$ is to decrease the underwriting risk ratio by 0.0185 (i.e. $0105942 \times 0.1749506$, where 0.1749506 is the mean of (RBC risk-weighted NPW/Premiums) $)_{t-1}$ for under-capitalised insurers.

51 (RBC risk-weighted Invested Asset/Assets) ${ }_{t}$ is higher by 0.001245 for under-capitalised insurers; and the impact of the under-capitalisation indicator variable interacted with the mean of (RBC risk-weighted Invested Asset/Assets) $)_{t-1}$ is -0.0018074 (i.e. $-0.143709^{*} 0.0125769$, where 0.0125769 is the mean of (RBC risk-weighted Invested Asset/Assets) $)_{-1}$ ) for under-capitalised insurers. 
adequately capitalised and under-capitalised insurers are positive and significant in the results for 1994-2007 in the asset risk equation but are insignificant for 1993. This signifies that asset risk increased after 1993 for marginally adequately capitalised insurers and under-capitalised insurers. In some models, asset risk is unrelated to capital (Surplus/Assets) ${ }_{t}$ (i.e. capitalisation). Further the speed of adjustment for underand marginally adequately capitalised insurers with respect to underwriting risk and especially asset risk are different between the periods 1993 and 1994-2007 in Tables 4 and 5. Taking together all the differences discussed here and earlier, it appears that a change took place for insurers with the imposition of RBC requirements in 1994. In particular, marginally adequately capitalised and under-capitalised insurers increased their asset risk from the prior year and the values for speed of adjustment to the target asset ratio increased substantially for under-capitalised insurers from 1993 to 1994 to 2007. These results support Hypothesis 3. Of course, these results should be viewed with some caution as data are rather limited in the pre-RBC period (1,887 observations) compared with post-RBC (26,671 observations).

The remainder of this discussion focuses on the other control variables. The results in the 1994-2007 period in Tables 4 and 5 are emphasised in the discussion. Size (measured as the log of assets) is negatively and significantly related to capital as expected, and it is also positively related to asset risk for the 1994-2007 period in Tables 4 and 5 as expected. It is unexpectedly negatively related to underwriting risk. Reinsurance usage is negatively related to capital and asset risks in Tables 4 and 5 for the period 1994-2007. Reinsurance usage is negatively related to underwriting risk in the 1993 period. The Herfindahl indices are mostly insignificant in the 1993 results in Tables 4 and 5, and they are positively related to asset risk as expected but negatively related to underwriting risk in the 1994 2007 results, which is unexpected. The coefficient for the group and mutual indicator variables are positive in the (Surplus/Asset) ${ }_{t}$ equation in Tables 4 and 5, and the mutual (group) indicator variable is positively (negatively) related to (RBC risk-weighted Asset/ Invested Assets) ${ }_{t}$ in Tables 4 and 5. However, the group indicator variable is significant only in Table 5. The results in Tables 6 and 7 largely conform to the above results.

In a robustness test, we address the concern about $\mathrm{RBC}$ phase-out aspects. That is, the $\mathrm{RBC}$ ratios for years prior to 1998 are not exactly comparable with the ratios for later years because of phase-out aspects of the RBC formula. Companies were allowed to count 80 per cent of reserve discounts as part of TAC in 1994, 60 per cent in 1995, 40 per cent in 1996 and 20 per cent in 1997. In 1998, all reserve discounts were phased out of the calculation of TAC. ${ }^{52}$ Therefore, we repeat our estimation for the postRBC period by estimating models using data for 1994-1998 and for 1998-2007, separately. The results from the two periods are qualitatively similar to what is reported here. We also repeat our post-RBC estimation using data from 1994 to 1995 and 1994 to 1996. The results do not change materially and are available from the authors upon request.

\footnotetext{
${ }^{52}$ Property and Casualty Industry RBC Results for 2010, NAIC staff. We would like to thank a referee for pointing this out.
} 


\section{Conclusion}

This research investigates the relationship between capital and risk in property-liability insurers for 1993 and for 1994-2007. The periods selected allow for comparisons in insurer behaviour for the period prior to $\mathrm{RBC}$ implementation and after. This research is important because the NAIC is currently undergoing a review of its solvency mechanisms, including $\mathrm{RBC}$ requirements. Therefore, it is important to know if increased capital requirements are accompanied by increased, offsetting increases in risk. Overall the results suggest that risk and capital are positively related. That is, a positive relationship was detected between capital and asset and underwriting risk, so that capital increases are associated with increases in investment and underwriting risk and (vice versa). This significant and positive relationship was not consistently significant in 1993, prior to the implementation of RBC requirements in 1994.

Further, both marginally adequately capitalised insurers and under-capitalised insurers generally adjusted to their target underwriting and asset risk ratios at a higher speed than well-capitalised insurers in the post-RBC period. But marginally adequately capitalised insurers and under-capitalised insurers also increased their underwriting risk and investment risk ratios (over the period 1994-2007). The net effect of this activity was to increase underwriting risk by almost 5 per cent for under-capitalised insurers.

Finally, it should be mentioned that an important limitation exists for studies of this type: the analysis cannot be used to determine whether insurers are operating at levels of risk that are too high or too low in any absolute sense. Nor do they guarantee that capital levels are adequate.

\section{Acknowledgements}

We are grateful to the two anonymous referees for their many constructive comments. We also appreciate the valuable comments from seminar participants at the WRIEC 2010 and the CCIRM 2011 annual meetings. Jiang Cheng gratefully acknowledges the financial support from the Scientific Research Foundation for the Returned Overseas Chinese Scholars (Grant \#2012940) and the Specialized Research Fund for the Doctoral Program of Higher Education (New Teachers Grant \#Z1025420) of the Ministry of Education of China.

\section{References}

Aggarwal, R. and Jacques, K.T. (2001) 'The impact of FDICIA and prompt corrective action on bank capital and risk: Estimates using a simultaneous equations model', Journal of Banking and Finance 25(6): 1139-1160.

Baranoff, E.G. and Sager, T.W. (2002) 'The relations among asset risk, product risk, and capital in the life insurance industry', Journal of Banking and Finance 26(6): 1181-1197.

Baranoff, E.G. and Sager, T.W. (2003) 'The interrelationship among organizational and distribution forms and capital and asset risk structures in the life insurance industry', Journal of Risk and Insurance 70(3): 375-400.

Baranoff, E.G., Papadopoulos, S. and Sager, T.W. (2007) 'Capital and risk revisited: A structural equation model approach for life insurers', Journal of Risk and Insurance 74(3): 653-681.

Cheng, J. and Weiss, M.A. (2012a) 'The role of RBC, hurricane exposure, bond portfolio duration, and macroeconomic and industry-wide factors in property-liability insolvency prediction', Journal of Risk and Insurance 79(3): 723-750. 
300

Cheng, J. and Weiss, M.A. (2012b) 'Capital structure in the property-liability insurance industry: Tests of the tradeoff and pecking order theory', Journal of Insurance Issues 35(1): 1-43.

Cummins, J.D., Grace, M.F. and Phillips, R.D. (1999) 'Regulatory solvency prediction in property-liability insurance: Risk-based capital, audit ratios, and cash flow simulation', Journal of Risk and Insurance 66(3): $417-458$

Cummins, J.D., Harrington, S.E. and Niehaus, G. (1994) 'Risk-based Capital Requirements for Propertyliability Insurers: A financial analysis', in E. Altman and I. Vanderhoof (eds) The Financial Dynamics of the Insurance Industry, Burr Ridge, IL: Irwin Professional Publishers, pp. 99-110.

Cummins, J.D., Harrington, S.E. and Klein, R.W. (1995) 'Insolvency experience, risk-based capital, and prompt corrective action in property-liability insurance', Journal of Banking \& Finance 19(3): 511-527.

Cummins, J.D. and Nini, G.P. (2002) 'Optimal capital utilization by financial firms: Evidence from the property-liability insurance industry', Journal of Financial Services Research 21(1): 15-53.

Cummins, J.D. and Sommer, D.W. (1996) 'Capital and risk in property-liability insurance markets', Journal of Banking and Finance 20(6): 1069-1092.

Flannery, M.J. and Rangan, K.P. (2006) 'Partial adjustment toward target capital structures', Journal of Financial Economics 79(3): 469-506.

Harrington, S.E. and Niehaus, G. (2002) 'Capital structure decisions in the insurance industry: Stocks versus mutuals', Journal of Financial Services Research 21(1): 145-163.

Huang, R. and Ritter, J. (2009) 'Testing theories of capital structure and estimating the speed of adjustment', Journal of Financial and Quantitative Analysis 44(2): 237-271.

Intriligator, M.D. (1978) Econometric Models, Techniques and Applications, Englewood Cliffs, NJ: Prentice-Hall.

Jacques, K. and Nigro, P. (1997) 'Risk-Based capital, portfolio risk, and bank capital: A simultaneous equations approach', Journal of Economics and Business 49(6): 533-547.

Jokipii, T. and Milne, A. (2011) 'Bank capital buffer and risk adjustment decisions', Journal of Financial Stability 7(3): 165-178.

Koziol, C. and Lawrenz, J. (2009) 'What makes a bank risky? Insights from the optimal capital structure of banks', Journal of Banking and Finance 33(5): 861-873.

Mayers, D. and Smith Jr, C.W. (1992) 'Executive compensation in the life insurance industry', Journal of Business 65(1): 51-74.

Mayers, D. and Smith Jr, C.W. (2005) 'Agency problems and the corporate charter', The Journal of Law, Economics, \& Organization 21(2): 417-440.

Mayers, D., Shivdasani, A. and Smith Jr, C.W. (1997) 'Board composition and corporate control: Evidence from the insurance industry', Journal of Business 70(1): 33-62.

Ovtchinnikov, A.V. (2010) 'Capital structure decisions: Evidence from deregulated industries', Journal of Financial Economics 95(2): 249-274.

Petroni, K.R. and Shackelford, D.A. (1996) The Effect of Risk-Based Capital on Life Insurers' Investment, Working Paper No. 96-21, Philadelphia: University of Pennsylvania, Wharton Financial Institutions Center (March).

Shim, J. (2010) 'Capital-based regulation, portfolio risk and capital determination: Empirical evidence from the U.S. property-liability insurers', Journal of Banking \& Finance 34(10): 2450-2461.

Shrieves, R.E. and Dahl, D. (1992) 'The relationship between risk and capital in commercial banks', Journal of Banking \& Finance 16(2): 439-457.

Weiss, M. (1985) 'A multivariate analysis of loss reserving estimates in property-liability insurers', Journal of Risk and Insurance 52(2): 199-221. 


\section{Appendix}

Table A1 Three-stage least squares results (RBC risk-weighted Invested Asset/Invested Assets), used as dependent variable all insurers

\begin{tabular}{|c|c|c|c|c|c|c|}
\hline \multirow{2}{*}{$\frac{\text { Results for year }(s)}{\text { Dependent variable }}$} & \multicolumn{3}{|c|}{1993} & \multicolumn{3}{|c|}{ 1994-2007 with year dummies } \\
\hline & $\begin{array}{l}\text { (Surplus/ } \\
\text { Assets) }\end{array}$ & $\begin{array}{c}\text { (Risky Lines } \\
\text { NPW/ } \\
\text { Premiums) }\end{array}$ & $\begin{array}{c}\text { (RBC risk-weighted } \\
\text { Invested Asset/ } \\
\text { Invested Assets) }{ }_{t}\end{array}$ & $\begin{array}{l}\text { (Surplus/ } \\
\text { Assets) }\end{array}$ & $\begin{array}{c}\text { (Risky Lines } \\
\text { NPW/Premiums) }\end{array}$ & $\begin{array}{l}\text { (RBC risk-weighted } \\
\text { Invested Asset/ } \\
\text { Invested Assets) }\end{array}$ \\
\hline \multicolumn{7}{|l|}{ Independent variables } \\
\hline Intercept & $\begin{array}{l}0.041198 \\
(1.464)\end{array}$ & $\begin{array}{l}-0.031796 \\
(-1.014)\end{array}$ & $\begin{array}{l}-0.005322 * \\
(-1.842)\end{array}$ & $\begin{array}{l}0.088391 * * * \\
(11.156)\end{array}$ & $\begin{array}{l}-0.006001 \\
(-0.688)\end{array}$ & $\begin{array}{l}-0.004606^{* * *} \\
(-6.223)\end{array}$ \\
\hline$(\text { Geographic Herfindahl })_{t-1}$ & $\begin{array}{l}0.002294 \\
(0.404)\end{array}$ & $\begin{array}{l}0.012429^{* *} \\
(1.963)\end{array}$ & $\begin{array}{l}0.000193 \\
(0.331)\end{array}$ & $\begin{array}{l}-0.003003^{* *} \\
(-1.984)\end{array}$ & $\begin{array}{l}-0.004911^{* * *} \\
(-3.002)\end{array}$ & $\begin{array}{l}0.000280^{* *} \\
(2.007)\end{array}$ \\
\hline$(\text { Lines of Business Herfindahl })_{t-1}$ & $\begin{array}{l}-0.005037 \\
(-0.671)\end{array}$ & $\begin{array}{l}-0.006278 \\
(-0.751)\end{array}$ & $\begin{array}{l}0.000566 \\
(0.733)\end{array}$ & $\begin{array}{l}-0.007780^{* * *} \\
(-3.940)\end{array}$ & $\begin{array}{l}0.007431 \text { *** } \\
(3.493)\end{array}$ & $\begin{array}{l}0.000075 \\
(0.415)\end{array}$ \\
\hline 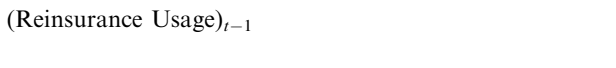 & $\begin{array}{l}-0.010067 \\
(-1.468)\end{array}$ & $\begin{array}{l}-0.019291 * * \\
(-2.527)\end{array}$ & $\begin{array}{l}-0.000719 \\
(-1.020)\end{array}$ & $\begin{array}{l}-0.009999 * * * \\
(-5.552)\end{array}$ & $\begin{array}{l}-0.000591 \\
(-0.304)\end{array}$ & $\begin{array}{l}-0.000745^{* * *} \\
(-4.497)\end{array}$ \\
\hline (Group Indicator (=1 if group) $)_{t-1}$ & $\begin{array}{l}-0.005373 \\
(-1.137)\end{array}$ & $\begin{array}{l}-0.000071 \\
(-0.014)\end{array}$ & $\begin{array}{l}-0.000343 \\
(-0.707)\end{array}$ & $\begin{array}{l}0.003117^{* *} \\
(2.382)\end{array}$ & $\begin{array}{l}-0.002218 \\
(-1.567)\end{array}$ & $\begin{array}{l}-0.000132 \\
(-1.090)\end{array}$ \\
\hline (Mutual Indicator $(=1 \text { if mutual) })_{t-1}$ & $\begin{array}{l}0.00292 \\
(0.602)\end{array}$ & $\begin{array}{l}-0.005287 \\
(-0.979)\end{array}$ & $\begin{array}{l}0.001043^{* *} \\
(2.099)\end{array}$ & $\begin{array}{l}0.005355^{* * *} \\
(3.730)\end{array}$ & $\begin{array}{l}-0.000938 \\
(-0.604)\end{array}$ & $\begin{array}{l}0.000816^{* * *} \\
(6.185)\end{array}$ \\
\hline $\log \left(\right.$ Assets $\left._{t-1}\right)$ & $\begin{array}{l}-0.000206 \\
(-0.148)\end{array}$ & $\begin{array}{l}0.002134 \\
(1.393)\end{array}$ & $\begin{array}{l}0.000306^{* *} \\
(2.175)\end{array}$ & $\begin{array}{l}-0.001863 * * * \\
(-4.889)\end{array}$ & $\begin{array}{l}0.000568 \\
(1.372)\end{array}$ & $\begin{array}{l}0.000343^{* * *} \\
(9.807)\end{array}$ \\
\hline (Risky Lines NPW/Surplus) ${ }_{t}$ & $\begin{array}{l}0.012021^{*} \\
(1.857)\end{array}$ & & $\begin{array}{l}-0.000067 \\
(-0.099)\end{array}$ & $\begin{array}{l}0.007024 * * * \\
(4.072)\end{array}$ & & $\begin{array}{l}0.000092 \\
(0.580)\end{array}$ \\
\hline (RBC risk-weighted Invested Assets/Invested Assets) ${ }_{t}$ & $\begin{array}{l}0.274134 * * \\
(2.322)\end{array}$ & $\begin{array}{l}-0.144985 \\
(-1.098)\end{array}$ & & $\begin{array}{l}0.204065^{* * *} \\
(6.549)\end{array}$ & $\begin{array}{l}-0.044703 \\
(-1.319)\end{array}$ & \\
\hline (Surplus/Assets) $_{t-1}$ & $\begin{array}{l}0.906671 * * * \\
(78.206)\end{array}$ & & & $\begin{array}{l}0.882615^{* * * *} \\
(272.672)\end{array}$ & & \\
\hline (Marginally Adequate Capitalisation & 0.00681 & 0.002041 & 0.000743 & 0.003411 & 0.004729 & $0.000459^{*}$ \\
\hline$(=1$ if marginally adequate capitalisation $))_{t-1}$ & $(0.273)$ & $(0.189)$ & $(0.677)$ & $(0.576)$ & $(1.644)$ & $(1.700)$ \\
\hline$(\text { Undercapitalised }(=1 \text { if under-capitalised }))_{t-1}$ & $\begin{array}{l}-0.010595 \\
(-0.801)\end{array}$ & $\begin{array}{l}-0.005251 \\
(-0.394)\end{array}$ & $\begin{array}{l}0.001455 \\
(1.213)\end{array}$ & $\begin{array}{l}-0.001298 \\
(-0.317)\end{array}$ & $\begin{array}{l}0.035418^{* * *} \\
(7.962)\end{array}$ & $\begin{array}{l}0.001183^{* * *} \\
(3.259)\end{array}$ \\
\hline $\begin{array}{l}\text { (Surplus/Assets) } t-1 *(\text { Marginally Adequate Capitalisation } \\
(=1 \text { if marginally adequate capitalisation) })_{t-1}\end{array}$ & $\begin{array}{l}-0.060406 \\
(-0.578)\end{array}$ & & & $\begin{array}{l}0.005227 \\
(0.267)\end{array}$ & & \\
\hline
\end{tabular}




\begin{tabular}{|c|c|c|c|c|c|c|}
\hline \multirow{2}{*}{$\frac{\text { Results for year }(s)}{\text { Dependent variable }}$} & \multicolumn{3}{|c|}{1993} & \multicolumn{3}{|c|}{ 1994-2007 with year dummies } \\
\hline & $\begin{array}{c}\text { (Surplus/ } \\
\text { Assets) }\end{array}$ & $\begin{array}{c}\text { (Risky Lines } \\
N P W / \\
\text { Premiums) }_{t}\end{array}$ & $\begin{array}{l}\text { (RBC risk-weighted } \\
\text { Invested Asset/ } \\
\text { Invested Assets) })_{t}\end{array}$ & $\begin{array}{l}\text { (Surplus/ } \\
\text { Assets) }\end{array}$ & $\begin{array}{c}\text { (Risky Lines } \\
\text { NPW/Premiums })_{t}\end{array}$ & $\begin{array}{c}\text { (RBC risk-weighted } \\
\text { Invested Asset/ } \\
\text { Invested Assets) }{ }_{t}\end{array}$ \\
\hline $\begin{array}{l}\text { (Surplus/Assets }) t-1 *(\text { Undercapitalised } \\
(=1 \text { if under-capitalised }))_{t-1}\end{array}$ & $\begin{array}{l}-0.025737 \\
(-0.448)\end{array}$ & & & $\begin{array}{l}-0.015957 \\
(-1.145)\end{array}$ & & \\
\hline$\left(\right.$ Surplus/Assets) ${ }_{t}$ & & $\begin{array}{l}0.022041 \\
(1.553)\end{array}$ & $\begin{array}{l}0.003613^{* * *} \\
(2.793)\end{array}$ & & $\begin{array}{l}0.008842 * * \\
(2.288)\end{array}$ & $\begin{array}{l}0.001994^{* * *} \\
(6.079)\end{array}$ \\
\hline (Risky Lines NPW/Premiums) $t-1$ & & $\begin{array}{l}0.948872 * * * \\
(125.363)\end{array}$ & & & $\begin{array}{l}0.958566^{* * * *} \\
(500.636)\end{array}$ & \\
\hline$($ Risky Lines NPW $) t-1 \times($ Marginally Adequate & & 0.033036 & & & 0.00084 & \\
\hline Capitalisation $(=1$ if marginally adequate capitalisation $))_{t-1}$ & & $(1.408)$ & & & $(0.133)$ & \\
\hline $\begin{array}{l}(\text { Risky Lines NPW }) t-1 \times(\text { Under-capitalised } \\
(=1 \text { if under-capitalised }))_{t-1}\end{array}$ & & $\begin{array}{l}0.049041 * * \\
(2.158)\end{array}$ & & & $\begin{array}{l}-0.029554 * * * \\
(-3.932)\end{array}$ & \\
\hline (RBC risk-weighted Invested Assets/Invested Assets) $)_{t-1}$ & & & $\begin{array}{l}0.907283^{* * *} \\
(78.966)\end{array}$ & & & $\begin{array}{l}0.913027^{* * *} \\
(336.714)\end{array}$ \\
\hline (RBC risk-weighted Invested Assets/Invested & & & $-0.142175^{* * *}$ & & & $-0.046291 * * *$ \\
\hline $\begin{array}{l}(\text { RBC risk-weighted Invested Assets/Invested Assets })_{t-1} \times \\
(\text { Undercapitalised }(=1 \text { if under-capitalised }))_{t-1}\end{array}$ & & & $\begin{array}{l}0.08398 \\
(1.474)\end{array}$ & & & $\begin{array}{l}-0.144824 * * * \\
(-8.925)\end{array}$ \\
\hline$R$-squared & 0.867 & 0.927 & 0.814 & 0.822 & 0.925 & 0.856 \\
\hline Number of observations. & 1,887 & 1,887 & 1,887 & 26,671 & 26,671 & 26,671 \\
\hline
\end{tabular}

Notes: *;*;*** significant at 10,5 and 1 per cent levels, respectively. $z$-statistics in parentheses below coefficients.

Risky Lines NPW is the sum of premiums written in risky lines that have the highest NPW risk factor loadings. RBC risk-weighted Invested Assets is the sum of $\mathrm{RBC}$ asset risk factor by type $\times$ asset type. Reinsurance usage is ceded loss reserves/Total direct and assumed loss reserves. An insurer is considered to be marginally adequately capitalised if $2 \leqslant \mathrm{RBC}$ ratio $<3$ and under-capitalised if $\mathrm{RBC}$ ratio $<2$. 
Table A2 Three-stage least squares results (Risky Invested Assets/Invested Assets) $t$ used as dependent variable (all insurers)

\begin{tabular}{|c|c|c|c|c|c|c|}
\hline \multirow{2}{*}{$\frac{\text { Results for year }(s)}{\text { Dependent variable }}$} & \multicolumn{3}{|c|}{1993} & \multicolumn{3}{|c|}{ 1994-2007 with year dummies } \\
\hline & $\begin{array}{l}\text { (Surplus/ } \\
\text { Assets) }\end{array}$ & $\begin{array}{l}\text { (Risky Lines } \\
\quad N P W / \\
\text { Premiums }_{t}\end{array}$ & $\begin{array}{c}\text { (Risky Invested } \\
\text { Assets/Invested } \\
\text { Assets) })_{t}\end{array}$ & $\begin{array}{l}\text { (Surplus/ } \\
\text { Assets) }\end{array}$ & $\begin{array}{l}\text { (Risky Lines } \\
\quad N P W / \\
\text { Premiums }_{t}\end{array}$ & $\begin{array}{c}\text { (Risky Invested } \\
\text { Assets/Invested } \\
\text { Assets) }{ }_{t}\end{array}$ \\
\hline \multicolumn{7}{|l|}{ Independent variables } \\
\hline Intercept & $\begin{array}{l}0.035123 \\
(1.259)\end{array}$ & $\begin{array}{l}-0.030532 \\
(-0.985)\end{array}$ & $\begin{array}{l}-0.007601 \\
(-0.333)\end{array}$ & $\begin{array}{l}0.086652 \text { *** } \\
(11.021)\end{array}$ & $\begin{array}{l}-0.007255 \\
(-0.839)\end{array}$ & $\begin{array}{l}-0.033702 * * * \\
(-6.352)\end{array}$ \\
\hline$(\text { Geographic Herfindahl })_{t-1}$ & $\begin{array}{l}0.001921 \\
(0.338)\end{array}$ & $\begin{array}{l}0.012612 * * \\
(1.994)\end{array}$ & $\begin{array}{l}0.003357 \\
(0.723)\end{array}$ & $\begin{array}{l}-0.003193^{* *} \\
(-2.110)\end{array}$ & $\begin{array}{l}-0.004871^{* * *} \\
(-2.978)\end{array}$ & $\begin{array}{l}0.002561^{* *} \\
(2.540)\end{array}$ \\
\hline (Lines of Business Herfindahl $)_{t-1}$ & $\begin{array}{l}-0.005234 \\
(-0.695)\end{array}$ & $\begin{array}{l}-0.006555 \\
(-0.783)\end{array}$ & $\begin{array}{l}0.003052 \\
(0.496)\end{array}$ & $\begin{array}{l}-0.007540 * * * \\
(-3.812)\end{array}$ & $\begin{array}{l}0.007228 * * * \\
(3.392)\end{array}$ & $\begin{array}{l}-0.000357 \\
(-0.272)\end{array}$ \\
\hline (Reinsurance Usage $)_{t-1}$ & $\begin{array}{l}-0.010223 \\
(-1.489)\end{array}$ & $\begin{array}{l}-0.019431^{* *} \\
(-2.545)\end{array}$ & $\begin{array}{l}-0.001876 \\
(-0.335)\end{array}$ & $\begin{array}{l}-0.010010^{* * *} \\
(-5.558)\end{array}$ & $\begin{array}{l}-0.000791 \\
(-0.407)\end{array}$ & $\begin{array}{l}-0.005199^{* * *} \\
(-4.343)\end{array}$ \\
\hline$(\text { Group Indicator }(=1 \text { if group }))_{t-1}$ & $\begin{array}{l}-0.00518 \\
(-1.094)\end{array}$ & $\begin{array}{l}-0.000215 \\
(-0.041)\end{array}$ & $\begin{array}{l}-0.00173 \\
(-0.449)\end{array}$ & $\begin{array}{l}0.003282 * * \\
(2.505)\end{array}$ & $\begin{array}{l}-0.002321 \\
(-1.638)\end{array}$ & $\begin{array}{l}-0.001742 * * \\
(-1.993)\end{array}$ \\
\hline$(\text { Mutual Indicator }(=1 \text { if mutual }))_{t-1}$ & $\begin{array}{l}0.003328 \\
(0.682)\end{array}$ & $\begin{array}{l}-0.005097 \\
(-0.941)\end{array}$ & $\begin{array}{l}0.008274 * * \\
(2.086)\end{array}$ & $\begin{array}{l}0.005158^{* * *} \\
(3.575)\end{array}$ & $\begin{array}{l}-0.00057 \\
(-0.366)\end{array}$ & $\begin{array}{l}0.006454 * * * \\
(6.743)\end{array}$ \\
\hline $\log \left(\right.$ Assets $\left._{t-1}\right)$ & $\begin{array}{c}0.000 \\
(0.120)\end{array}$ & $\begin{array}{c}0.002 \\
(1.376)\end{array}$ & $\begin{array}{l}0.001 \\
(0.572)\end{array}$ & $\begin{array}{l}-0.001779 * * * \\
(-4.719)\end{array}$ & $\begin{array}{c}0.001 \\
(1.600)\end{array}$ & $\begin{array}{l}0.002397^{* * *} \\
(9.567)\end{array}$ \\
\hline 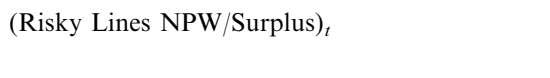 & $\begin{array}{l}0.011859^{*} \\
(1.831)\end{array}$ & & $\begin{array}{c}0.0002 \\
(0.037)\end{array}$ & $\begin{array}{l}0.007014^{* * *} \\
(4.066)\end{array}$ & & $\begin{array}{l}0.000124 \\
(0.107)\end{array}$ \\
\hline (Risky Invested Assets/ Invested Assets) ${ }_{t}$ & $\begin{array}{l}0.025209^{*} \\
(1.673)\end{array}$ & $\begin{array}{l}-0.019516 \\
(-1.165)\end{array}$ & & $\begin{array}{l}0.027978^{* * * *} \\
(6.570)\end{array}$ & $\begin{array}{l}-0.010106^{* *} \\
(-2.182)\end{array}$ & \\
\hline$(\text { Surplus/Assets) })_{t-1}$ & $\begin{array}{l}0.909133^{* * *} \\
(78.805)\end{array}$ & & & $\begin{array}{l}0.882834 * * * \\
(273.454)\end{array}$ & & \\
\hline (Marginally Adequate Capitalisation & 0.006967 & 0.002441 & 0.009265 & 0.00335 & $0.004901^{*}$ & $0.003381 *$ \\
\hline$(=1$ if marginally adequate capitalisation $))_{t-1}$ & $(0.279)$ & $(0.226)$ & $(1.041)$ & $(0.566)$ & $(1.703)$ & $(1.744)$ \\
\hline$(\text { Undercapitalised }(=1 \text { if under-capitalised }))_{t-1}$ & $\begin{array}{l}-0.009178 \\
(-0.693)\end{array}$ & $\begin{array}{l}-0.005399 \\
(-0.405)\end{array}$ & $\begin{array}{l}0.012167 \\
(1.272)\end{array}$ & $\begin{array}{l}-0.001264 \\
(-0.308)\end{array}$ & $\begin{array}{l}0.035607 * * * \\
(8.003)\end{array}$ & $\begin{array}{l}0.009571 * * * \\
(3.704)\end{array}$ \\
\hline$(\text { Surplus/Assets })_{t-1} \times($ Marginally Adequate & -0.061374 & & & 0.005172 & & \\
\hline $\begin{array}{l}\text { Capitalisation }(=1 \text { if marginally adequate } \\
\text { capitalisation }))_{t-1} \\
(\text { Surplus/Assets })_{t-1} \times(\text { Undercapitalised }\end{array}$ & $\begin{array}{l}(-0.586) \\
-0.032153\end{array}$ & & & $\begin{array}{c}(0.264) \\
-0.016682\end{array}$ & & \\
\hline
\end{tabular}




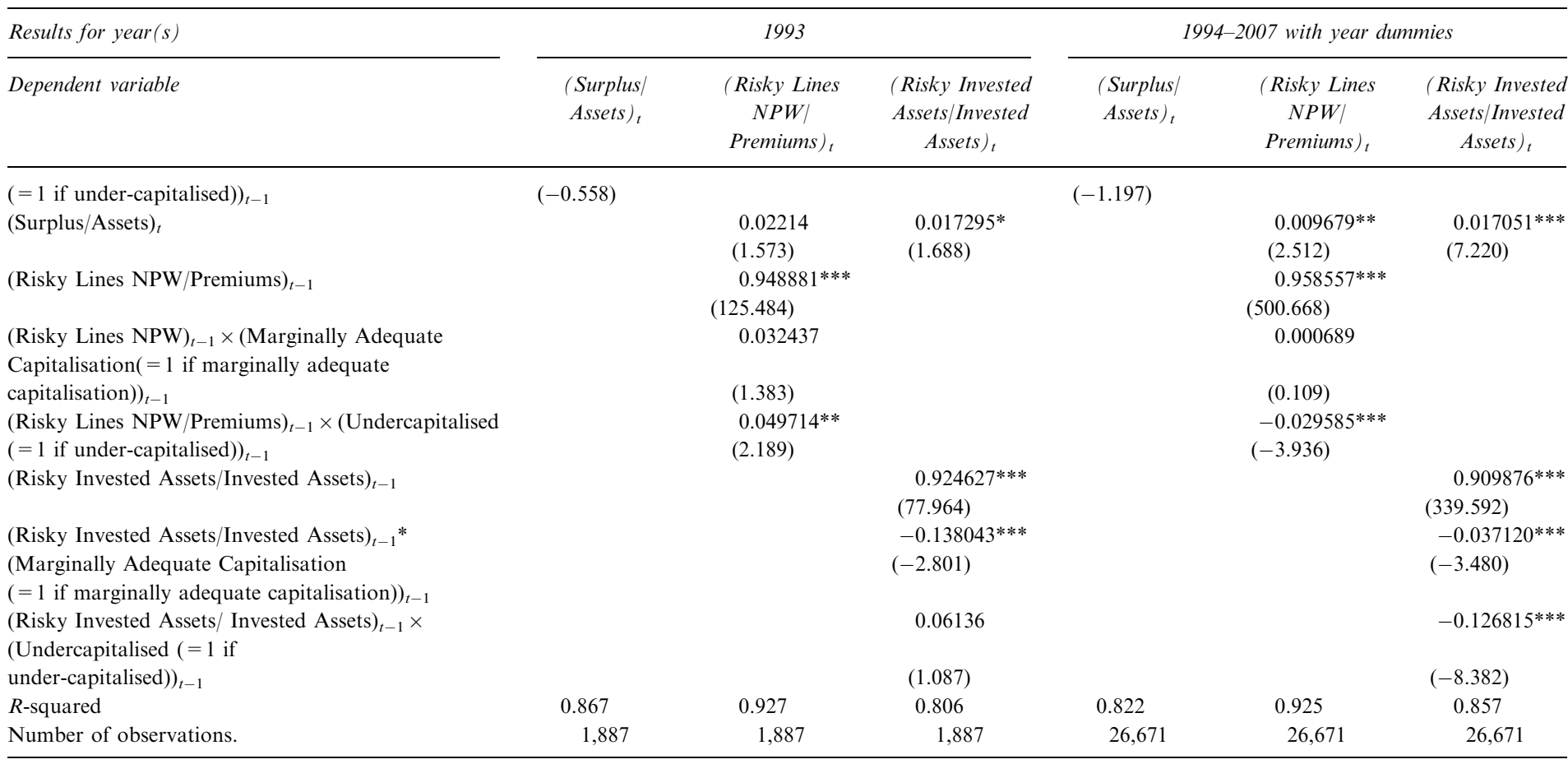

Notes: *; **; *** significant at 10,5 and 1 per cent levels, respectively. $z$-statistics in parentheses below coefficients.

Risky Lines NPW is the sum of premiums written in risky lines that have the highest NPW risk factor loadings. Reinsurance usage is ceded loss reserves/Total direct and assumed loss reserves. An insurer is considered to be marginally adequately capitalised if $2 \leqslant \mathrm{RBC}$ ratio $<3$ and under-capitalised if $\mathrm{RBC}$ ratio $<2$. Risky Invested Assets are the sum of stock and real estate investments. 
Table A3 Three-stage least squares results (RBC risk-weighted Invested Asset/Invested Assets) ${ }_{t}$ used as dependent variable (insurers with RBC ratio greater than 3)

\begin{tabular}{|c|c|c|c|c|c|c|}
\hline \multirow{2}{*}{$\frac{\text { Results for year }(s)}{\text { Dependent variable }}$} & \multicolumn{3}{|c|}{1993} & \multicolumn{3}{|c|}{ 1994-2007 with year dummies } \\
\hline & $\begin{array}{l}\text { (Surplus/ } \\
\text { Assets) }{ }_{t}\end{array}$ & $\begin{array}{l}\text { (Risky Lines } \\
\text { NPW/ } \\
\text { Premiums) }\end{array}$ & $\begin{array}{l}\text { (RBC risk-weighted } \\
\text { Invested Asset/ } \\
\text { Invested Assets) }\end{array}$ & $\begin{array}{l}\text { (Surplus/ } \\
\text { Assets) }{ }_{t}\end{array}$ & $\begin{array}{l}\text { (Risky Lines } \\
\text { NPW/ } \\
\text { Premiums) }\end{array}$ & $\begin{array}{l}\text { (RBC risk-weighted } \\
\text { Invested Asset/ } \\
\text { Invested Assets) }\end{array}$ \\
\hline \multicolumn{7}{|l|}{ Independent variables } \\
\hline Intercept & $\begin{array}{l}0.036887 \\
(1.258)\end{array}$ & $\begin{array}{l}-0.034953 \\
(-1.013)\end{array}$ & $\begin{array}{l}-0.007475^{* *} \\
(-2.525)\end{array}$ & $\begin{array}{l}0.081041^{* * *} \\
(9.804)\end{array}$ & $\begin{array}{l}-0.004351 \\
(-0.499)\end{array}$ & $\begin{array}{l}-0.004467 * * * \\
(-5.778)\end{array}$ \\
\hline$(\text { Geographic Herfindahl })_{t-1}$ & $\begin{array}{l}-0.001826 \\
(-0.315)\end{array}$ & $\begin{array}{l}0.013128^{*} \\
(1.940)\end{array}$ & $\begin{array}{l}0.000891 \\
(1.524)\end{array}$ & $\begin{array}{l}-0.002389 \\
(-1.528)\end{array}$ & $\begin{array}{l}-0.004517^{* * *} \\
(-2.791)\end{array}$ & $\begin{array}{l}0.000320^{* *} \\
(2.217)\end{array}$ \\
\hline (Reinsurance Usage $)_{t-1}$ & $\begin{array}{l}-0.014648 * * \\
(-2.099)\end{array}$ & $\begin{array}{l}-0.019601^{* *} \\
(-2.410)\end{array}$ & $\begin{array}{l}-0.000636 \\
(-0.905)\end{array}$ & $\begin{array}{l}-0.010096^{* * *} \\
(-5.388)\end{array}$ & $\begin{array}{l}-0.000187 \\
(-0.097)\end{array}$ & $\begin{array}{l}-0.000642 * * * \\
(-3.719)\end{array}$ \\
\hline (Group Indicator (=1 if group) $)_{t-1}$ & $\begin{array}{l}-0.008736^{*} \\
(-1.801)\end{array}$ & $\begin{array}{l}0.00061 \\
(0.108)\end{array}$ & $\begin{array}{l}-0.000709 \\
(-1.453)\end{array}$ & $\begin{array}{l}0.002773^{* *} \\
(2.039)\end{array}$ & $\begin{array}{l}-0.002362 * \\
(-1.676)\end{array}$ & $\begin{array}{l}-0.000229^{*} \\
(-1.826)\end{array}$ \\
\hline (Mutual Indicator $(=1$ if mutual $))_{t-1}$ & $\begin{array}{l}0.002518 \\
(0.505)\end{array}$ & $\begin{array}{l}-0.003772 \\
(-0.648)\end{array}$ & $\begin{array}{l}0.000957 * \\
(1.910)\end{array}$ & $\begin{array}{l}0.006119 * * * \\
(4.166)\end{array}$ & $\begin{array}{l}-0.00102 \\
(-0.670)\end{array}$ & $\begin{array}{l}0.000785^{* * *} \\
(5.812)\end{array}$ \\
\hline $\log \left(\right.$ Assets $\left._{t-1}\right)$ & $\begin{array}{l}0.000271 \\
(0.186)\end{array}$ & $\begin{array}{l}0.002199 \\
(1.300)\end{array}$ & $\begin{array}{l}0.000435^{* * *} \\
(3.008)\end{array}$ & $\begin{array}{l}-0.001498^{* * *} \\
(-3.752)\end{array}$ & $\begin{array}{l}0.000427 \\
(1.026)\end{array}$ & $\begin{array}{l}0.000342^{* * * *} \\
(9.311)\end{array}$ \\
\hline 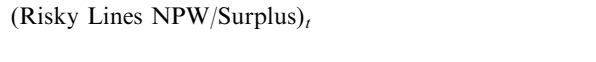 & $\begin{array}{l}0.020660 * * * \\
(2.989)\end{array}$ & & $\begin{array}{l}-0.000179 \\
(-0.254)\end{array}$ & $\begin{array}{l}0.008566^{* * * *} \\
(4.705)\end{array}$ & & $\begin{array}{l}0.000077 \\
(0.457)\end{array}$ \\
\hline (RBC risk-weighted Invested Assets/Invested Assets) ${ }_{t}$ & $\begin{array}{l}0.277737 * * \\
(2.319)\end{array}$ & $\begin{array}{l}-0.112783 \\
(-0.801)\end{array}$ & & $\begin{array}{l}0.206658^{* * *} \\
(6.508)\end{array}$ & $\begin{array}{l}-0.041999 \\
(-1.268)\end{array}$ & \\
\hline$(\text { Surplus/Assets })_{t-1}$ & $\begin{array}{l}0.903293 * * * \\
(78.438)\end{array}$ & & & $\begin{array}{l}0.882993 * * * \\
(273.172)\end{array}$ & & \\
\hline (Surplus/Assets) ${ }_{t}$ & & $\begin{array}{l}0.017727 \\
(1.196)\end{array}$ & $\begin{array}{l}0.003286^{* * *} \\
(2.579)\end{array}$ & & $\begin{array}{l}0.007924 * * \\
(2.091)\end{array}$ & $\begin{array}{l}0.001798 * * * \\
(5.348)\end{array}$ \\
\hline$(\text { Risky Lines NPW/Premiums) })_{t-1}$ & & $\begin{array}{l}0.949210^{* * *} \\
(123.017)\end{array}$ & & & $\begin{array}{l}0.957989 * * * \\
(528.889)\end{array}$ & \\
\hline 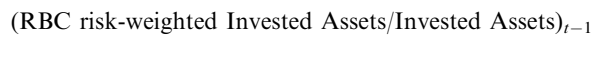 & & & $\begin{array}{l}0.906658 * * * \\
(82.121)\end{array}$ & & & $\begin{array}{l}0.914089^{* * *} \\
(339.037)\end{array}$ \\
\hline$R$-squared & 0.867 & 0.919 & 0.834 & 0.816 & 0.93 & 0.863 \\
\hline Number of observations. & 1,688 & 1,688 & 1,688 & 24,174 & 24,174 & 24,174 \\
\hline
\end{tabular}

Notes: $* ; * ; * *$ significant at 10,5 and 1 per cent levels, respectively. $z$-statistics in parentheses below coefficients.

Risky Lines NPW is the sum of premiums written in risky lines that have the highest NPW risk factor loadings. RBC risk-weighted Invested Assets is the sum of $\mathrm{RBC}$ asset risk factor by type $\times$ asset type. Reinsurance usage is ceded loss reserves/Total direct and assumed loss reserves. An insurer is considered to be marginally adequately capitalised if $2 \leqslant \mathrm{RBC}$ ratio $<3$ and under-capitalised if $\mathrm{RBC}$ ratio $<2$. 
Table A4 Three-stage least squares results (Risky Invested Assets/Invested Assets) $t$ used as dependent variable (insurers with RBC ratio greater than 3)

\begin{tabular}{|c|c|c|c|c|c|c|}
\hline \multirow{2}{*}{$\frac{\text { Results for year }(s)}{\text { Dependent variable }}$} & \multicolumn{3}{|c|}{1993} & \multicolumn{3}{|c|}{ 1994-2007 with year dummies } \\
\hline & $\begin{array}{l}\text { (Surplus/ } \\
\text { Assets) }\end{array}$ & $\begin{array}{l}\text { (Risky Lines } \\
\text { NPW/ } \\
\text { Premiums) }{ }_{t}\end{array}$ & $\begin{array}{c}\text { (Risky Invested } \\
\text { Assets/Invested } \\
\text { Assets) }{ }_{t}\end{array}$ & $\begin{array}{l}\text { (Surplus/ } \\
\text { Assets) }{ }_{t}\end{array}$ & $\begin{array}{l}\text { (Risky Lines } \\
\text { NPW/ } \\
\text { Premiums) }\end{array}$ & $\begin{array}{c}\text { (Risky Invested } \\
\text { Assets/Invested } \\
\text { Assets) }_{t}\end{array}$ \\
\hline \multicolumn{7}{|l|}{ Independent variables } \\
\hline Intercept & $\begin{array}{l}0.031336 \\
(1.080)\end{array}$ & $\begin{array}{l}-0.0348 \\
(-1.022)\end{array}$ & $\begin{array}{l}-0.025022 \\
(-1.073)\end{array}$ & $\begin{array}{l}0.078804 * * * \\
(9.602)\end{array}$ & $\begin{array}{l}-0.005643 \\
(-0.653)\end{array}$ & $\begin{array}{l}-0.033736^{* * * *} \\
(-6.100)\end{array}$ \\
\hline 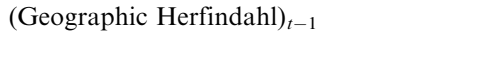 & $\begin{array}{l}-0.002054 \\
(-0.354)\end{array}$ & $\begin{array}{l}0.013271^{* *} \\
(1.962)\end{array}$ & $\begin{array}{l}0.007624 \\
(1.643)\end{array}$ & $\begin{array}{l}-0.002569 \\
(-1.643)\end{array}$ & $\begin{array}{l}-0.004485 * * * \\
(-2.771)\end{array}$ & $\begin{array}{l}0.002592^{* *} \\
(2.493)\end{array}$ \\
\hline$(\text { Lines of Business Herfindahl })_{t-1}$ & $\begin{array}{l}-0.001267 \\
(-0.164)\end{array}$ & $\begin{array}{l}-0.002048 \\
(-0.227)\end{array}$ & $\begin{array}{l}0.001312 \\
(0.212)\end{array}$ & $\begin{array}{l}-0.007121 * * * \\
(-3.494)\end{array}$ & $\begin{array}{l}0.009700 * * * \\
(4.612)\end{array}$ & $\begin{array}{l}0.00014 \\
(0.103)\end{array}$ \\
\hline (Reinsurance Usage $)_{t-1}$ & $\begin{array}{l}-0.014720^{* *} \\
(-2.107)\end{array}$ & $\begin{array}{l}-0.019737 * * \\
(-2.427)\end{array}$ & $\begin{array}{l}-0.00107 \\
(-0.192)\end{array}$ & $\begin{array}{l}-0.010200 * * * \\
(-5.444)\end{array}$ & $\begin{array}{l}-0.000364 \\
(-0.188)\end{array}$ & $\begin{array}{l}-0.004299 * * * \\
(-3.456)\end{array}$ \\
\hline$(\text { Group Indicator }(=1 \text { if group }))_{t-1}$ & $\begin{array}{l}-0.008535^{*} \\
(-1.757)\end{array}$ & $\begin{array}{l}0.000483 \\
(0.086)\end{array}$ & $\begin{array}{l}-0.00414 \\
(-1.070)\end{array}$ & $\begin{array}{l}0.002922 * * \\
(2.145)\end{array}$ & $\begin{array}{l}-0.002476^{*} \\
(-1.755)\end{array}$ & $\begin{array}{l}-0.002297 * * \\
(-2.535)\end{array}$ \\
\hline$(\text { Mutual Indicator }(=1 \text { if mutual }))_{t-1}$ & $\begin{array}{l}0.00263 \\
(0.523)\end{array}$ & $\begin{array}{l}-0.003397 \\
(-0.580)\end{array}$ & $\begin{array}{l}0.008275^{* *} \\
(2.070)\end{array}$ & $\begin{array}{l}0.006008 * * * \\
(4.066)\end{array}$ & $\begin{array}{l}-0.000659 \\
(-0.431)\end{array}$ & $\begin{array}{l}0.006440 * * * \\
(6.585)\end{array}$ \\
\hline $\log \left(\right.$ Assets $\left._{t-1}\right)$ & $\begin{array}{l}0.000591 \\
(0.412)\end{array}$ & $\begin{array}{l}0.002211 \\
(1.329)\end{array}$ & $\begin{array}{l}0.001652 \\
(1.453)\end{array}$ & $\begin{array}{l}-0.001381 * * * \\
(-3.492)\end{array}$ & $\begin{array}{l}0.000516 \\
(1.253)\end{array}$ & $\begin{array}{l}0.002443^{* * *} \\
(9.318)\end{array}$ \\
\hline (Risky Invested Assets/Invested Assets) ${ }_{t}$ & $\begin{array}{l}0.029723^{*} \\
(1.943)\end{array}$ & $\begin{array}{l}-0.017634 \\
(-0.985)\end{array}$ & & $\begin{array}{l}0.027015^{* * *} \\
(6.198)\end{array}$ & $\begin{array}{l}-0.009510^{* *} \\
(-2.094)\end{array}$ & \\
\hline (Surplus/Assets) $_{t-1}$ & $\begin{array}{l}0.905061 * * * \\
(79.085)\end{array}$ & & & $\begin{array}{l}0.883453 * * * \\
(273.919)\end{array}$ & & \\
\hline$\left(\right.$ Surplus/Assets) ${ }_{t}$ & & $\begin{array}{l}0.018047 \\
(1.229)\end{array}$ & $\begin{array}{l}0.015824 \\
(1.573)\end{array}$ & & $\begin{array}{l}0.008724 * * \\
(2.310)\end{array}$ & $\begin{array}{l}0.015430 * * * \\
(6.390)\end{array}$ \\
\hline (Risky Lines NPW/Premiums) $_{t-1}$ & & $\begin{array}{l}0.949240^{* * *} \\
(123.131)\end{array}$ & & & $\begin{array}{l}0.957981 * * * \\
(528.943)\end{array}$ & \\
\hline 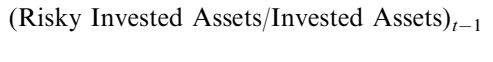 & & & $\begin{array}{l}0.922696^{* * *} \\
(81.263)\end{array}$ & & & $\begin{array}{l}0.910434 * * * \\
(342.843)\end{array}$ \\
\hline$R$-squared & 0.867 & 0.919 & 0.827 & 0.816 & 0.93 & 0.865 \\
\hline Number of observations. & 1,688 & 1,688 & 1,688 & 24,174 & 24,174 & 24,174 \\
\hline
\end{tabular}

Notes: $* ; * ; * * *$ significant at 10,5 and 1 per cent levels, respectively. $z$-statistics in parentheses below coefficients

Risky Lines NPW is the sum of premiums written in risky lines that have the highest NPW risk factor loadings. Reinsurance usage is ceded loss reserves/Total direct and assumed loss reserves. An insurer is considered to be marginally adequately capitalised if $2 \leqslant \mathrm{RBC}$ ratio $<3$ and under-capitalised if $\mathrm{RBC}$ ratio $<2$. Risky Invested Assets are the sum of stock and real estate investments. 


\begin{abstract}
About the Authors
Jiang Cheng, PhD is Assistant Professor of Finance at the School of Finance, Shanghai University of Finance and Economics, Shanghai, China. His main research interests are corporate governance, regulation, accounting manipulation, and empirical aspects of finance and insurance

Mary A. Weiss, PhD is Deaver Professor of Risk, Insurance and Healthcare Management at Temple University and a past president of the premier insurance academic organisation in the United States, the American Risk and Insurance Association. She is the editor of Risk Management and Insurance Review and a co-editor for the Journal of Risk and Insurance. Her research has focused on financial services conglomeration, efficiency measurement of insurers, no-fault automobile insurance, reinsurance, regulation and underwriting cycles.
\end{abstract}

